PNNL-11061

UC-810

Project Technical Information

Critique of Hanford Waste Vitrification

Plant Off-Gas Sampling Requirements

RECEIVED

APR 011996

R. W. Goles

OSTI

March 1996

Prepared for

the U.S. Department of Energy

under Contract DE-AC06-76RLO 1830

Pacific Northwest National Laboratory

Richland, Washington 99352 
PNNL-1 1061

UC-810

Project Technical Information

\section{Critique of Hanford Waste Vitrification Plant Off-Gas Sampling Requirements}

R. W. Goles

March 1996

Prepared for

the U.S. Department of Energy

under Contract DE-AC06-76RLO 1830

Pacific Northwest National Laboratory

Richland, Washington 99352

Reprint of historical document HWVP-89-IVJ0020500B, dated September 1989. Data, formatting, and other conventions reflect standards at the original date of printing. Technical peer reviews and editorial reviews may not have been performed. 


\title{
DISCLAIMER
}

This report was prepared as an account of work sponsored by an agency of the United States Government. Neither the United States Government nor any agency thereof, nor Battelle Memorial Insititute, nor any of their employees, makes any warranty, express or implied, or assumes any legal liability or responsibility for the accuracy, completeness, or.usefulness of any information, apparatus, product, or process disclosed, or represents that its use would not infringe privately owned. rights. Reference herein to any specific commercial product, process, or service by trade name, trademark, manufacturer, or otherwise does not necessarily constitute or imply its endorsement, recommendation, or lavoring by the United States Government or any agency thereof, or Battelle Memorial institute. The views and opinions of authors expressed herein do not necessarily state or reflect those of the United States Government or any agency thereof.

\author{
PACIFIC NORTHWEST NATIONAL LABORATORY \\ operated by \\ BATTELLE \\ for the \\ UNITED STATES DEPARTMENT OF ENERGY \\ under Contract DE-AC06-76RLO 1830
}

Printed in the Uniled States of America

Available to DOE and DOE contractors from the

Office of Scientivic and Technical Information, P.O. Box 62, Oak Ridge, TN 37831;

prices available from (615) 576-8401.

Available to the public from the National Technical information Service,

U.S. Department of Commerce, 5285 Port Royal Rd., Springfield, VA 22161 
Off-gas sampling and monitoring activities needed to support operational safety, process control, waste form qualification, and environmental protection requirements of the Hanford Waste Vitrification Plant (HWVP) have been evaluated. The locations of necessary sampling sites have been identified on the basis of plant requirements, and the applicability of Defense Waste Processing Facility (DWPF) reference sampling equipment to these HWVP requirements has been assessed for all sampling sites. Equipment deficiencies, if present, have been described and the bases for modifications and/or alternative approaches have been developed. The findings of this evaluation are summarized below.

- Operational safety concerns require that process off-gas combustibles be monitored. Because of the uncertain impact of control air dilution upon detection sensitivity and measurement accuracy, melter off-gas combustibles should be sampled from the quench scrubber exhaust stream. Since the process vessel vent system does not include a similar dilution system, sampling for combustibles can be simplified by collecting the sample after HEPA filtration. Existing DWPF sampler configurations are adequate for flammability monitoring, provided the gases are well mixed at the sampling point and the monitored sample stream is free of all condensed phase effluent (water mists and aerosols). The use of lower explosive limit detector systems is recommended for this monitoring task, but operability needs to be verified under HWVP off-gas conditions.

- Process control of the selective catalytic $\mathrm{NO}_{x}$ destructor requires process monitoring of $\mathrm{NO}_{x}$ influent concentrations. The $\mathrm{NO}_{x}$ monitor location should be chosen to minimize sample delivery and analysis time so $\mathrm{NH}_{3}$ injection rates will match $\mathrm{NO}_{x}$ concentrations at the destructor. Representativeness criteria require that sampling lines be heat traced throughout their entire length. A similar sampling capability must also be established at the destructor's exhaust to allow efficiency measurements to be made and to monitor for residual $\mathrm{NH}_{3}$ concentrations for safety purposes. Heat tracing of sample lines is a mandatory requirement for representative sampling of $\mathrm{NH}_{3}$ effluent.

- To provide direct equipment performance data (DFs), off-gas sampling capabilities need to be established before and after each active off-gas treatment device. Remote samplers, designed to monitor the performance of aerosol abatement equipment at the planned DWPF facility, cannot provide truly representative process data and therefore cannot, in genera7, be used to measure HWVP equipment DFs. These samplers can, however, supply performance-related data that can be used with other process parameters to effectively support off-gas system and process operations. The performance of gaseous effluent abatement devices can 
be adequately supported by DWPF reference samplers, provided that sample and/or moisture conderisation does not occur in sample transport lines. Because of the proximity of the plant's contact-maintained off-gas support area to these gas scrubbing devices, means of eliminating sample line condensation are significantly simplifjed and readily achievable.

- Waste form qualification models cannot be supported directly by process off-gas (POG) sampling, since unquenched off-gas sampling is not practical and quenched off-gas samples cannot meet the representativeness criterion. It is recommended that liquid waste stream compositional data be employed to account for POG system losses in these models.

- For environmental protection purposes, it is recommended that stack emissions of ${ }^{3},{ }^{14} \mathrm{C}$, ${ }^{129}{ }_{I}$, radioactive aerosols and $\mathrm{NO}_{\mathrm{X}}$ be continuously monitored. Commercially available stack monitoring systems can fully support all HWVP effluent emission regulatory requirements. Sampling sensitivities, calibration procedures, and reporting requirements, as defined by the regulatory authorities, are documented in WHC-CH-7-5. $\mathrm{CO}_{\mathrm{X}}$ and $\mathrm{H}_{2} \mathrm{O}$ (vapor) stack monitors may also be useful if specific activity measurements of $C$ and $H$ are to be measured in batch samples.

- Performance sampling requirements established in the HWVP Technical Data Package (TDP) cannot be strictly met by existing remote sampling technologies. Specifically, remote aerosol sampling configurations cannot meet the representativeness criteria except at a few off-gas system sampling sites. The bases of TDP off-gas sampling requirements therefore need to be re-evaluated and modified in.accordance with the results of this study.

- DWPF remote sampling configurations can adequately support off-gas system operations when sampling data are used in conjunction with other process parameters. Although performance-related off-gas sampling data cannot be used as direct stand-alone indicators of off-gas system operational efficiency, they can, when combined and correlated with other process data, provide adequate diagnostic information to satisfy operational engineering needs. 


\section{GLOSSARY OF ACRONYMS}

DCG

Derived concentration guides

DF

Decontamination factor

DOE

Department of Energy

DWPF

Defense Waste Processing Facility

EPA

Environmental Protection Agency

FDC

Functional design criteria

HEPA

High-efficiency particulate air

HLLW

High-level liquid waste

HVAC

Heating, ventilation, and air conditioning

HWVP

Hanford Waste Vitrification Plant

LEL

Lower explosive Timit

LFCM

Liquid-fed ceramic melter

LOI

Letter of intent

MOG

Melter off gas

PNL

Pacific Northwest Laboratory

POG

Process off gas

PVV

Process vessel vent

SBS

Submerged-bed scrubber

SCR

Selective catalytic reduction

SRL

Savannah River Laboratory

TDP

Technical Data Package

WHC

Westinghouse Hanford Company

WVNS

West Valley Nuclear Service

$x_{2}$

Halogens 


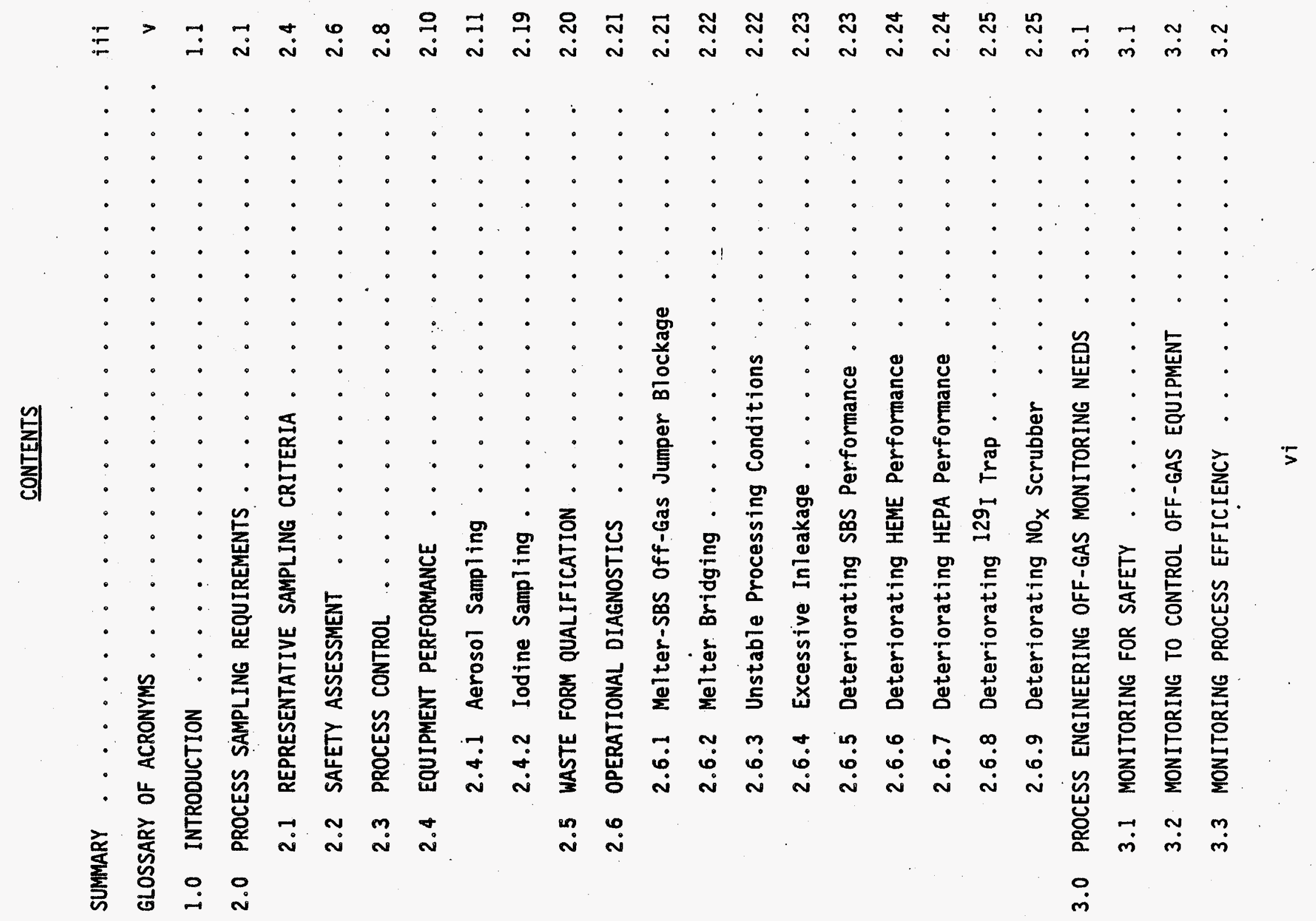


3.4.1 Submerged-Bed Scrubber .......... 3.3

3.4 .2 HEME and HEPA .................. 3.4

3.4 .3 Iodine Trap ................... 3.4

3.4.4 Selective Catalytic Reducer. . . . . . . 3.4

3.5 MONITORING TO IDENTIFY OFF-GAS SYSTEM PROBLEMS . . . . 3.6

3.6 OFF-GAS SAMPLING NEEDS AND REQUIREMENTS $\ldots \ldots \ldots$

4.0 ENVIRONMENTAL SAMPLING REQUIREMENTS . . . . . . . . . 4.1

4.1 RADIOACTIVE EFFLUENT SAMPLING REQUIREMENTS . . . . . 4.1

4.2 CHEMICAL EFFLUENT SAMPLING REQUIREMENTS $\ldots \ldots \ldots . \ldots 4$

5.0 COMPARISON OF SAMPLING RECOMMENDATIONS . . . . . . . 5.1

5.1 MELTER . . . . . . . . . . . . . . . 5.1

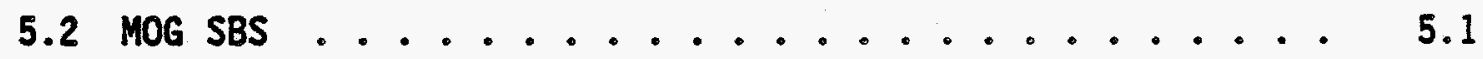

5.3 HEME ................................ 5.3

5.4 MOG HEPA ......................... 5.3

5.5 IODINE HEATER ........................ 5.4

5.6 IODINE BED ............................ 5.4

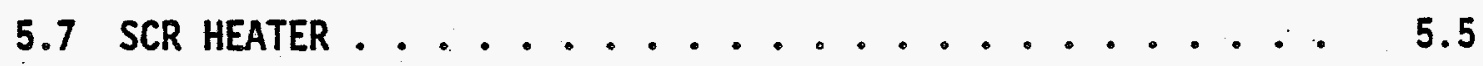

5.8 SCR OR SCR COOLER ..................... 5.5

5.9 PVV SBS AND HEPA . . ................ 5.5

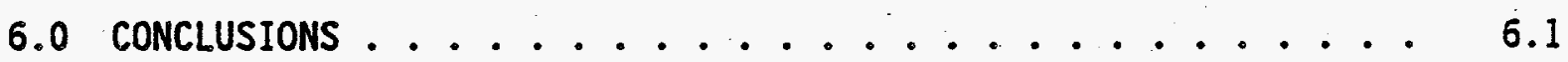

7.0 REFERENCES ................................ 7.1

APPENDIX: REMOTE AEROSOL MONITOR DESCRIPTION ........ A.1 


\section{FIGURES}

1 HWVP Process Off-Gas System ............. 1.2

2 OWPF Piping for Gas Sample Stations with LEL Monitors . . . . 2.2

3 DWPF Piping for Gas Sample Stations with Spool Pieces . . . 2.3

\section{TABLES}

1 LFCM Process Failure Mode Identification and Problem

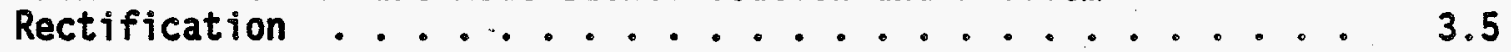

2 Comparison of HWVP Process Sampling Requirements and Process Operational Sampling Needs ........... 3.7

3 Comparison of Sampling Recommendations for the HWVP ..... 5.2

4 Summary of Recommended Sampling Sites and Their Function . . . 6.3 


\subsection{INTRODUCTION}

The Hanford Waste Vitrification PIant (HWVP) is being designed to utilize liquid-fed ceramic melter (LFCM) technology to vitrify the pretreated high-level liquid defense waste (HLLW) currently being stored in underground tanks on the Hanford Site in southeastern Washington. Because vitrification is a high-temperature process that generates significant chemical and radiological effluents, an off-gas processing system has been designed to abate, hazardous LFCM emissions before the process exhaust is released to the environment. A separate but less aggressive off-gas system has also been constructed to treat effluent emissions generated by the vessel system supporting the HWVP melter. A schematic of the overall HWVP process off-gas (POG) system is illustrated in Figure 1. A single selective catalytic reduction (SCR) system is used to abate $\mathrm{NO}_{X}$ from both systems after the off-gas streams are combined. The combined off-gas stream is subsequently mixed with the building's heating, ventilation, and air conditioning (HVAC) system before going though several stages of final filtration (not shown) preceding environmental release.

Process off-gas composition is an important HWVP operating parameter, as equipment control, safety conditions and plant operating permits will be based upon it. Product quality may also, in part, be influenced by off-gas compositional data insofar as process losses may significantly affect the mass balance around the melter and thereby influence the waste form qualification model. Recognizing the importance of off-gas composition to plant operations, the HWVP Technical Data Package (TDP), SW-HWV-DP-001, includes requirements for a process sampling system that is to provide off-gas compositional data for operational safety, process control, equipment performance evaluation, and waste form qualification. In addition, the Functional Design 


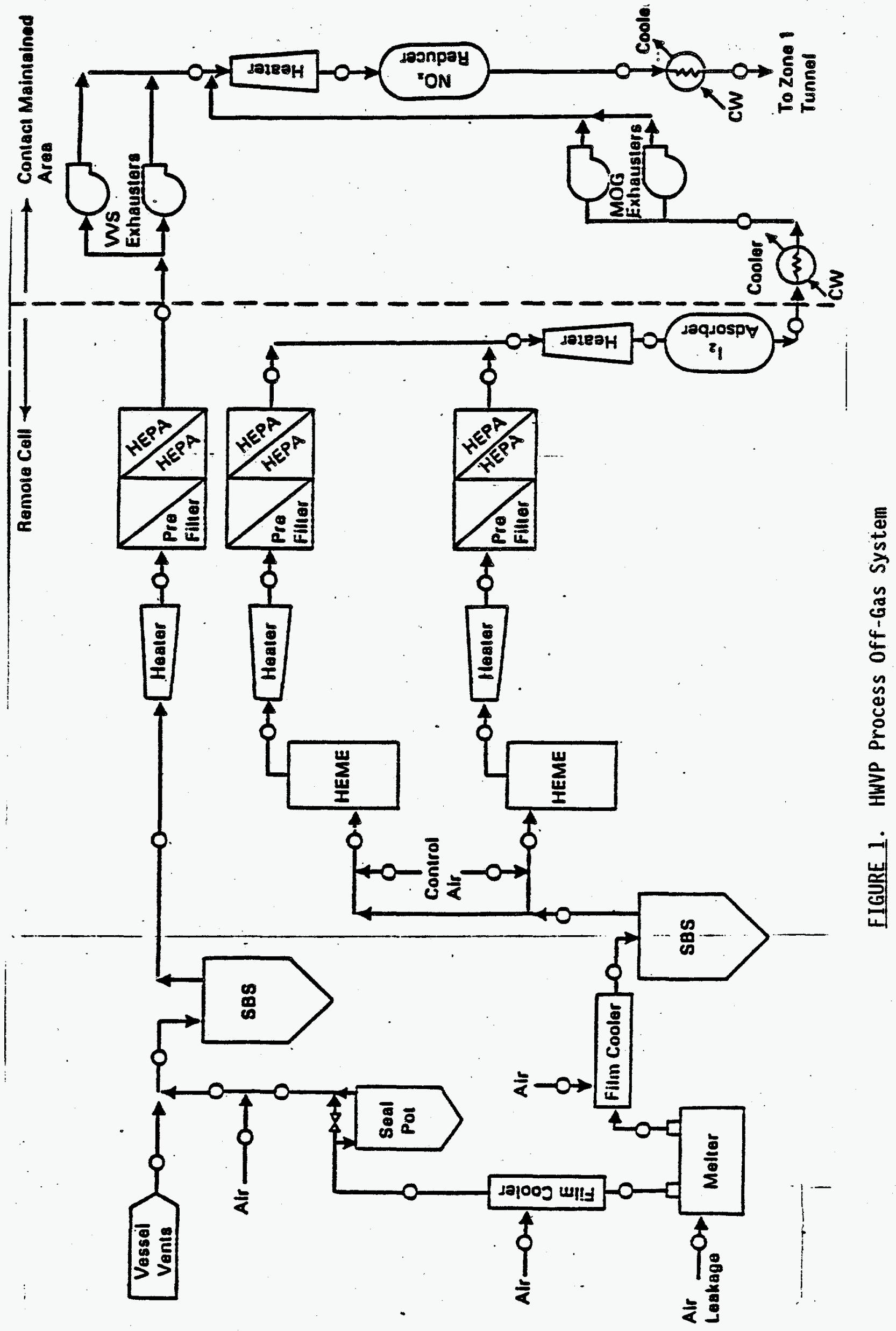

\section{2}


Criteria (FDC), SD-HWV-FDC-001, specify that the HWVP POG system will have sufficient capacity to decontaminate radioactive process emissions at the stack to meet $\mathrm{plant}$ boundary limit requirements as defined by WHC-CM-7-5 (WHC 1989a). (a) This later provision requires that stack sampling be conducted to verify operational compliance with public exposure limits. According to WHC-CM-7-5, plant releases of chemical effluents are governed by either specific stack emission limits, occupational health and safety criteria (permissible exposure limits), ambient air quality standards imposed at plant boundaries, or a prevention of significant (environmental) deterioration (PSD) permit issued by federal, state, and/or local regulating authorities, whichever is applicable.

Thus it is clear that plant operations will be dependent, to some extent, upon both process and environmental sampling results. The type of samples required, the location of sampling points and the nature of sampling equipment used have not been specifically established either in the FDC or in the TDP supporting HWVP design. This technical report will address these off-gas sampling questions and attempt to resolve technology and design issues related to this subject. The scope of this HWVP sampling assessment, as defined by Westinghouse Hanford's (WHC's) Letter of Instruction (LOI) and Pacific Northwest Laboratory's (PNL's) Technical Work P7an, includes the following technical objectives.

- Establish and evaluate HWVP off-gas sampling requirements.

- Identify sampling criteria needed to meet these requirements.

- Assess the applicability of DWPF, West Valley Nuclear Services (WVNS), and foreign sampling system technologies to the HWVP.

- Document bases and developments needed to satisfy HWVP sampling requirements.

- Define requirements for system imptementation.

This report will first examine remote process sampling requirements, and then discuss the type of sampling that is likely to be needed to

(a) When the FDC were written, the relevant manual was RHO-MA-139, Environmental Protection Manual (Rockwell Hanford Operation, 1987). It was superseded by WHC-CM-7-5. 
demonstrate operational compliance with plant regulatory emission limits. Results of this evaluation will then be compared with sampling recommendations of Fluor Daniels (CWBS 3602.05). Conclusions of this evaluation will then be presented, followed by a summary of recommendations. 


\subsection{PROCESS SAMPLING REQUIREMENTS}

As a requirement of the HWVP TDP, gas samples will be collected from the HWVP POG system in order to assess and verify operational safety, to control off-gas processing conditions, to evaluate equipment performance and to verify waste form qualification models. Sampling sites and equipment required to support these sampling and/or monitoring requirements have been modeled after applicable DWPF designs. (a) Figures 2 and 3 illustrate the DWPF sampler configurations that have been tentatively adopted for use by the HWVP.

The sampling system illustrated in Figure 2 is a dual-purpose sampling loop designed to monitor off-gas flammability conditions and to measure offgas aerosol concentrations. Real-time lower explosive limit (LEL) detectors and an integrating absolutè air filter are used to accomplish these off-gas monitoring and sampling tasks, respectively.

Figure 3 represents the general sampling configuration designed to support all other sampling requirements. Like the dual-purpose sampler, the general sampling system also possesses aerosol filtration capabilities; however, customized gaseous sampling capabilities are also supported by the generalized system in that the demountable spool piece can be replaced by gas analyzers, gas scrubbers, and/or sorption devices.

Since DWPF (and HWVP) process samplers are (will be) located in shielded analytical cells or hoods that are remote from POG sampling points, POG samples have to be drawn through long runs of unheated piping to sampler locations where the process effluent is monitored and/or collected.(b) Implicit in the design of these process samplers is the assumption that the sampled gas presented to the process samplers faithfully represents off-gas conditions at the process sampling site, or, alternatively, that these conditions can be somehow derived or calculated from sampling results. Before proceeding to a discussion of the individual TDP-based in-cell process sampling

(a) Reference Conceptual Design, HWVP Technical Description and Drawings, SD-HWV-TI-007, Rev 0, Book 3, SK-2-90794.

(b) Basic Data Report, DWPF Sludge Plant, DPSP 80-1033, Savannah River Laboratory and HWVP TDP. 


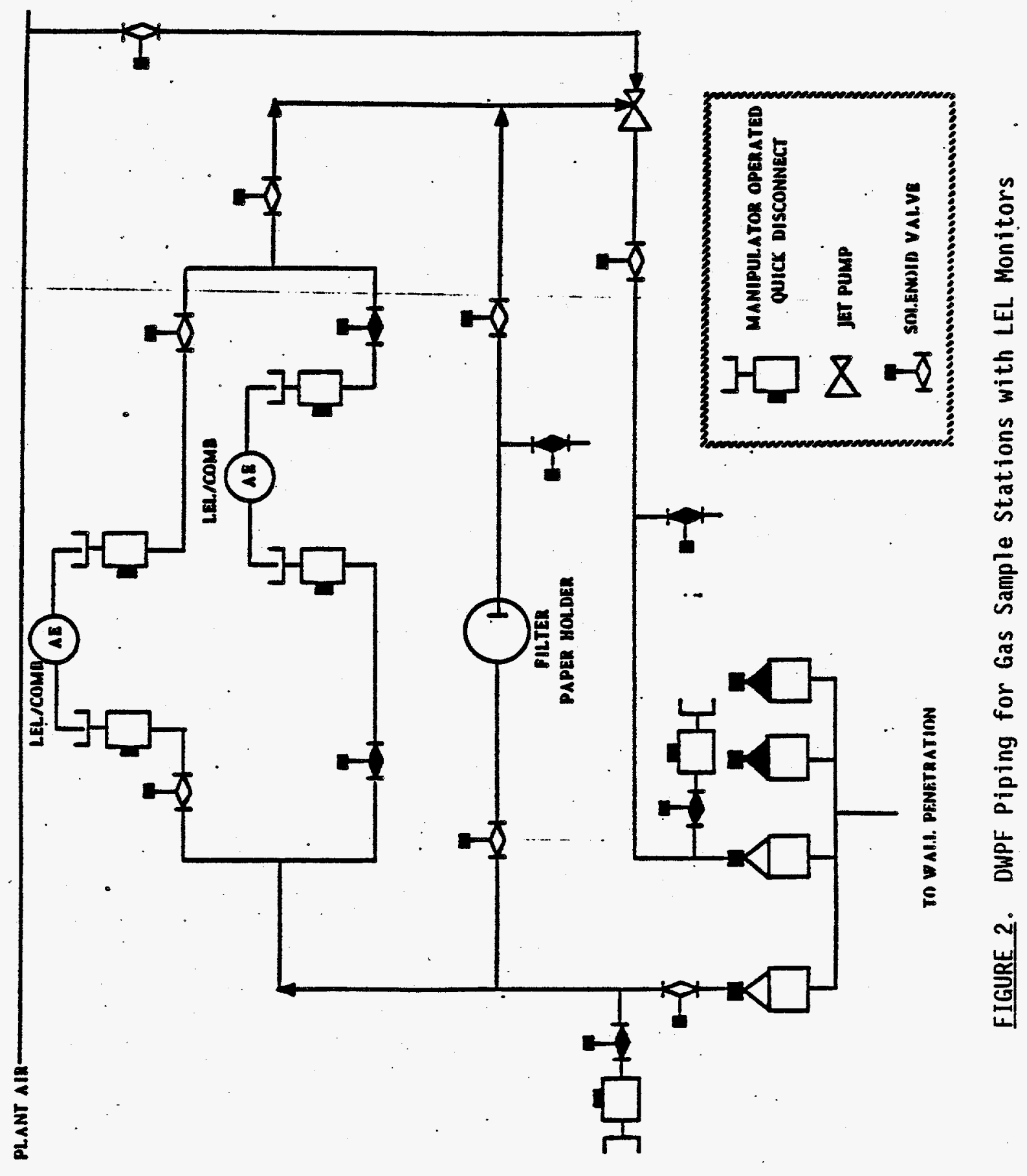

2.2 


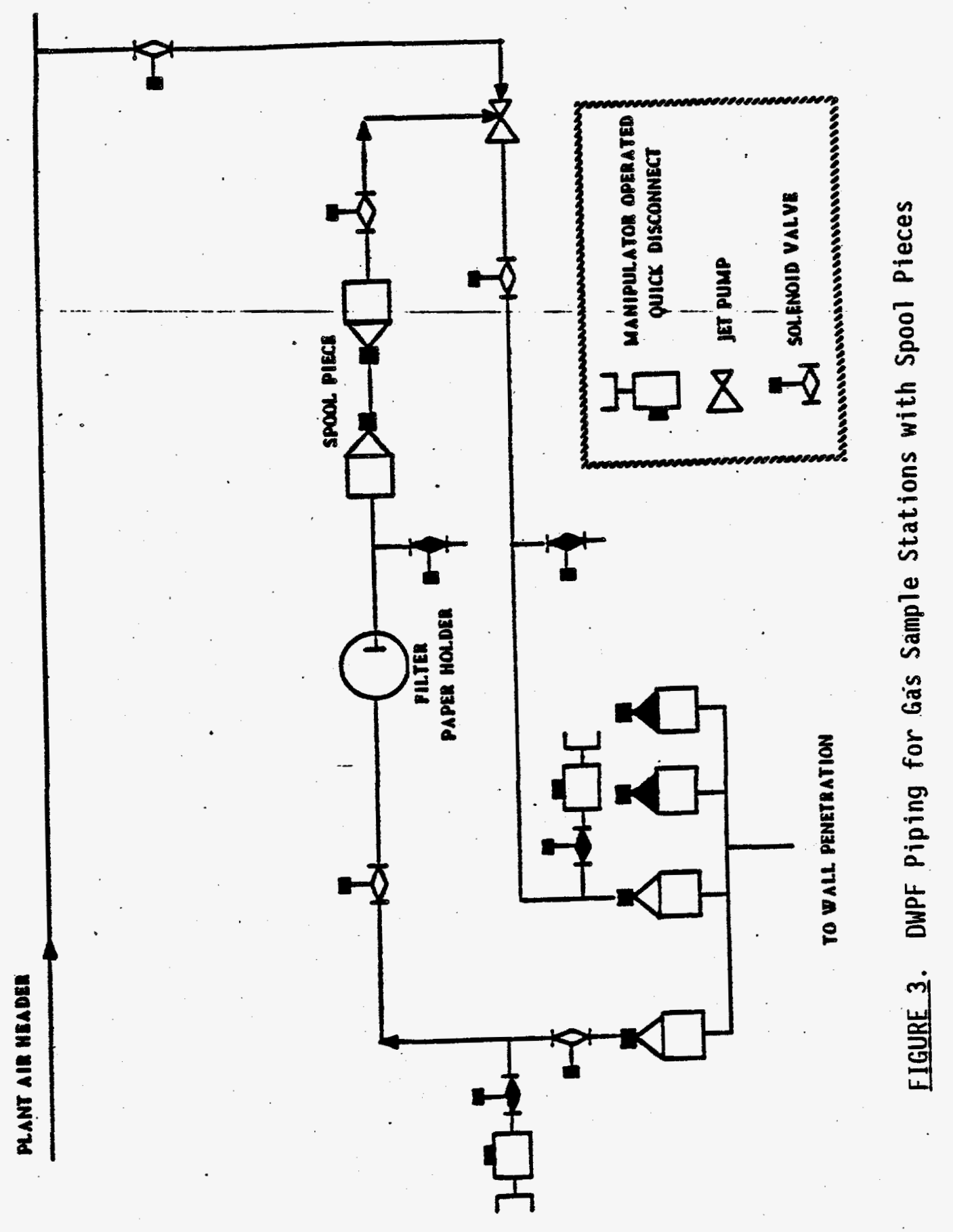


requirements previously described, it is important to evaluate the validity of the above assumption for current sampler designs, as the relevance of sampling results and requirements depends upon it.

\subsection{REPRESENTATIVE SAMPLING CRITERIA}

The HWVP TDP requires that the design of the gas sampling system allow representative samples to be obtained. To be representative, both trend and record samplers need to be exposed to average conditions that exist at process sampling sites. This requires that 1) sample gases be extracted from a representative sampling point, 2 ) the sample be extracted with a minimum bias, and 3) transport losses between the point of extraction and sample collection be small or at least well characterized.

If the exhaust stream to be sampled is perfectly mixed, the selection of a representative sampling location is trivial; however, there is evidence to indicate that particle concentration gradients exist even in long, well-mixed conduits (Sehmel 1973, 1970; Schwendiman and Glissmeyer 1976). Consequent1y, it is essential that multi-port sampling probes be used to transect the duct being sampled at a location which is at least 10 duct diameters downstream and 5 diameters upstream from any flow obstruction (Schwendiman, Stegen, and G1 issmeyer 1975). For gaseous effluents, however, no concentration stratification is possible unless duct gases are not well mixed. Because turbulent mixing of effluent gases will occur in the submerged-bed scrubber (SBS) during the quenching process, representative sampling conditions for gaseous effluents are ensured at all sampling locations downstream of the off-gas quencher, provided that melter vacuum control air is injected upstream of the SBS. If this is not the case, the representativeness of gas sampling sites downstream of the point of injection may be affected, depending upon the location of the site relative to the air injection point.

To minimize aerosol sample bias by the sample probe itself, turbulence caused by the presence of the probe nozzle in the sampled duct must be minimized. This is accomplished by matching sample gas extraction velocity to the duct velocity at the point of sample extraction; in other words, by achieving "isokinetic sampling conditions" (Sehme1 1973, 1970; Schwendiman, 
Stegen, and Glissmeyer 1975; Lundgren and Calvert 1967). For sample locations exhibiting significant flow rate variations, moreover, an interactive sampling system must be utilized that adjusts sampling rates according to the instantaneous conditions at the sampling site. Gas-phase effluents ( $\mathrm{NO}_{x}$, iodine, etc.) are not affected by sample probe bias and need not be extracted isokinetically.

Transmission losses occur for both aerosol and gaseous effluents. For aerosol effluent sampling, line losses are primarily caused by some combination of diffusion, gravity settling, eddy diffusion, turbulent impaction, and electrostatic forces.(a). To control or minimize these loss mechanisms,

- sampling lines should be as short as possible

- horizontal sections should be avoided or minimized

- sampling lines should be made of metal

- elbows, flow restrictions, and valves should be avoided

- sampling rates should be as high as possible without producing turbulent flow conditions (Thomas 1973; Strom 1972).

The primary transmission loss mechanisms associated with gaseous eff1uent are surface deposition and/or chemical interactions (Kabat 1982; Unrein et a1. 1984). To control and/or minimize gaseous sample line losses,

- sample lines should be as short as possible and chemically inert

- residence times in sample lines should be minimized

- unreactive filters should be used to remove aerosols

- sampling lines should be heat traced to preclude effluent and water vapor condensation.

It is clear from previous descriptions that the reference HWVP (DWPF adopted) POG sampling systems, which are illustrated in Figures 2 and 3 , do not strictiy comply with the representative sampling criteria just discussed. Although process aerosol collection systems fail to meet al.l criteria associated with representativeness, gas sampling capabilities are not as strongly

(a) Sehmel 1973, 1970; Schwendiman and Glissmeyer 1976; Schwendiman; Stegen, and G7issmeyer 1975; Lundgren and Calvert 1967; Thomas 1973; Strom 1972. 
compromised. The implication of sampler design deficiencies will be specifically addressed for each TDP-defined sampling requirement and design modification, and/or alternative approaches will be recommended to rectify or at least ameliorate sampler inadequacies.

\subsection{SAFETY ASSESSMENT}

Operational safety issues regarding meiter off-gas (MOG) flammability hazards require that the concentrations of $\mathrm{H}_{2}$ and $\mathrm{CO}$ be continuously monitored after off-gas quenching. The site from which sample gas is extracted must be well mixed and as close to the off-gas quencher as practical to minimize inleakage based dilution biases and to ensure that worst-case (flammability) conditions will always be measured. In any case, the sampling site must be upstream of the melter pressure control air injection point unless that site is located in the melter-SBS jumper. Otherwise, injected control air would reduce LEL response sensitivity (possibly severeiy if variable speed blowers are not used) and increase data uncertainties, as worst-case off-gas system conditions would have to be derived from several process variables. Homogeneity issues would also have to be addressed and resolved.

Since the process vessel vent (PVV) system is the backup for the MOG system, continuous flammability monitoring must al so be conducted after the PVV SBS quencher scrubber. However, uniike the MOG system, the PVV backup will not, at the present time, operate with a pressure control air injection system, thereby eliminating the impact of large and variable dilutions upon LEL sensitivity (see Figure 1). Therefore, PVV sampling for $\mathrm{H}_{2}$ and $\mathrm{CO}$ can and should be sampled after the PVV high-efficiency particulate air (HEPA) filter assembly, which will add to sampler reliability without sacrificing measurement accuracy. If however, control air is added to the post-SBS PVV off-gas system, a thorough safety evaluation should be conducted based on specific conditions at hand, or the SBS exhaust stream should be used for PVV f7ammability monitoring as it is for the MOG. The PVV f7ammability monitoring site will also serve to detect and alarm any significant buildup of radiolytic $\mathrm{H}_{2}$ in the PVV system. 
Lower flammability (expiosive) limit (LEL) detection devices normally used for organic combustibles have been successfully applied to and calibrated for mixtures of $\mathrm{H}_{2}$ and $\mathrm{CO}$ by the Savannah River Laboratory (SRL). These devices will be used to monitor off-gas flammability conditions in the DWPF using the sampler design illustrated in Figure 2. The LEL-based design has also been provisionally adopted for the HWVP.

Simple, reliable, rugged, and responsive, LELs are much less expensive to purchase, install, and operate than any other viable analytical alternative. Since LELs are proven, commercially available instruments with demonstrated LFCM off-gas monitoring capabilities, an LEL flammability detection device appears to be the method of choice for the HWVP; however, compatibility with the HWVP off-gas stream must be demonstrated, as the instrumental response of this device is based on catalytic activity that is subject to chemical poisoning.

Because $\mathrm{H}_{2}$ and $\mathrm{CO}$ are noncondensible gases and only slightly water soluble at projected sampling temperatures $\left(16^{\circ}-40^{\circ} \mathrm{C}\right)$, representative monitoring. of off-gas combustibility conditions can be achieved using the reference sampler design illustrated in Figure 2. However, the portion of the sample stream diverted to the LELs (slip stream) needs to be preconditioned by removal of all sample stream aerosols--liquid and particulate.(a) This will require heat tracing the piping carrying the sample slip stream to the LELs so that all entrained water droplets are vaporized before subsequent particulate filtration. Although commercial LELs are internally filtered, it is recommended that the internal filters be replaced with an external filter assembly that is. remotely replaceable, as collected aerosols will be radioactive.

The HWVP flammability monitoring system as presently designed is not an element in a process control 10op; consequently, there are no direct automated responses that result from the detection of a potentially hazardous condition. Instead, the HWVP flammability monitoring system only provides for an alarm function that will initiate an appropriate administrative

(a) Roy Nelson, Safety Products Manager, Scott Aviation, Lancaster, NY. 
response (melter feed termination). However, automatic process responses are not only possible, they may be necessary and beneficial, as the following discussion will revea?.

\subsection{PROCESS CONTROL}

Off-gas monitoring will be used as a process control tool for abating HWVP $\mathrm{NO}_{\mathrm{X}}$ emissions. The HWVP will employ a selective catalytic reduction (SCR) system to destroy process emissions of $\mathrm{NO}_{x}$ using an $\mathrm{NH}_{3}$ reductant. The catalyzed reduction reaction consumes $\mathrm{NH}_{3}$ and $\mathrm{NO}_{x}$ and produces only $\mathrm{N}_{2}$ and $\mathrm{H}_{2} \mathrm{O}$. The $\mathrm{NO}_{x}$ destruction efficiency of the SCR process is directly related to the $\mathrm{NH}_{3}: \mathrm{NO}_{x}$ molar ratio in the device's influent stream. Although other

parameters may aiso be used to regulate SCR operations, process concentration. of $\mathrm{NO}_{X}$ is a primary control element.

Because of the erratic manner in which slurry feed is dried, calcined, and melted, off-gas concentration of $\mathrm{NO}_{X}$ is a dynamic variable, even under ideal, steady-state LFCM processing conditions (Goles, Mishima, and Schmidt 1989); consequently, off-gas sample site selection and gas sample delivery methods are important considerations in establishing a we1l-operating SCR control strategy. Ideally, the ratio of $\mathrm{NH}_{3}$ to $\mathrm{NO}_{\mathrm{X}}$ in the SCR's influent stream would be fixed by an operational set point that would control $\mathrm{NH}_{3}$ injection rates according. to instantaneous concentration of $\mathrm{NO}_{X}$. This requires that the sampled gas be extracted upstream of the $\mathrm{NH}_{3}$ injection site and that sample delivery and analysis time be less than the average off-gas transit time between the sampling and injection sites. Although the hydrogen mordenite catalytic substrate is a reservoir for adsorbed $\mathrm{NH}_{3}$ and is somewhat forgiving of temporarily mismatched reactant ratios, non-optimal operations and residual SCR exhaust emissions of $\mathrm{NH}_{3}$ may result if high $\mathrm{NO}_{X}(\geq 90 \%)$ destruction efficiencies are required and a proper sampling strategy is not established and/or maintained. The above sampling requirements become less important at lower SCR operating efficiencies. Based on pilot-sCale SCR tests conducted at the WVNS site, residual $\mathrm{NH}_{3}$ concentrations exiting the SCR column should be insignificant for destruction efficiencies $\leq 80 \%$ (Goles 1989). 
Since proper operation of the SCR treatment system is directly linked to off-gas concentrations of $\mathrm{NO}_{\mathrm{x}}$, a representative gas sampling stream needs to be presented to the $\mathrm{NO}_{x}$ analyzer supporting SCR operations. The most important criterion for maintaining a representative $\mathrm{NO}_{\mathrm{x}}$ sample stream is to avoid condensation (effluent and/or water vapor) in any part of the sample delivery system, as $\mathrm{NO}_{2}$ is condensible and $\mathrm{NO}_{2}$ : $\mathrm{NO}$ ratios will be appreciable and variable at the SCR's off-gas system location. Because the boiling point of $\mathrm{NO}_{2}$ lies within the $\mathrm{FDC}$ cell design temperature range $\left(16^{\circ}-40^{\circ} \mathrm{C}\right)$ and because water vapor condensation will occur throughout a large part of this range, a $11 \mathrm{NO}_{x}$ sample transport lines must be heat (steam) traced right up to the $\mathrm{NO}_{\mathrm{x}}$ analyzer's sample conditioning system.

Based upon the above arguments, the HWV reference sampling system illustrated in Figure 3 should be capable of furnishing a useful process gas sample to the controlling $\mathrm{NO}_{\mathrm{x}}$ analysis system (located at the demountable spool piece in this illustration), provided all sample delivery lines are heat traced. Packaged sample conditioning and analysis systems designed for $\mathrm{NO}_{x}$ process monitoring applications are commercially available and totally compatible with SCR support requirements. Nevertheless, the filter assembly, if used, and all sampling lines in the sampler glove box should be heat traced right up to the $\mathrm{NO}_{\mathrm{x}}$ sample conditioning system. It should be noted that the $\mathrm{NO}_{\mathrm{X}}$ analyzer need not be remotely located, as the SCR is contained in a contact-maintained area. This situation also provides additional flexibility in gallery siting of the analyzer, as it is much easier to maintain a heat-traced line in a radiation zone than to operate and calibrate an analytical instrument in one. However, both alternatives are acceptable.

Although the above sampling and analysis system, when combined with an $\mathrm{NO}_{X}$ stack monitor, can provide average SCR abatement efficiency (provided flow rate measurements. are available), it is recommended that a second sampling point downstream of the SCR column be used with a second analysis system to collect $\mathrm{NO}_{x}$ effluent (efficiency) data and to monitor residual $\mathrm{NH}_{3}$ effluent concentrations. The efficiency information when combined with operational parameters will provide processing data that will be invaluable in diagnosing operational problems and projecting the service life of the catalytic bed. 
Analysis of $\mathrm{NH}_{3}$ in the SCR's effluent stream will also prove to be an invaluable aid for establishing when and if to replace the SCR's catalytic bed, should its catalytic activity degrade with time. Since SCR efficiency is directly related to the $\mathrm{NH}_{3}: \mathrm{NO}_{x}$ influent ratio, decreasing column efficiency can be compensated for by increasing this ratio. This will also increase the residual $\mathrm{NH}_{3}$ concentration in the $\mathrm{SCR}^{\prime} \mathrm{s}$ exhaust stream. Since $\mathrm{NH}_{3}$ and unreacted $\mathrm{NOx}$ can combine to form $\mathrm{NH}_{4} \mathrm{NO}_{3}$, which presents a potential off-gas flamability and explosive hazard should it accumulate, limits may have to be placed on allowable $\mathrm{NH}_{3}$ concentrations in the HWVP process exhaust. Commercial $\mathrm{NH}_{3}$ process instruments are available to support these off-gas monitoring needs, but they are quite expensive (\$75K) and, in a strict sense, continuous data are not needed.

Given the extreme reactivity of $\mathrm{NH}_{3}$ with moisture and the condensibility of $\mathrm{NO}_{x}$, the post-SCR sample delivery system must be heat traced throughout its entire length. As a result the reference DWPF sampler configuration illustrated in Figure 3 has to include heat tracing in order to provide a useful sample stream to the gas analysis system (spool piece). However, since the HWVP SCR is situated in a contact-maintained area, a great deal of flexibility exists concerning the siting of the post-SCR sample conditioning and collection or analysis systems.

\subsection{EQUIPMENT PERFORMANCE}

The purpose of the HWVP POG system is to abate effluent emissions directly generated by the vitrification process and by all plant support activities. To maintain overall POG system design.performance, a knowledge of operational efficiencies of individual off-gas system components is necessary in order to assess off-gas treatment system performance (DF) as specified in the HWVP TDP. Although many process indicators related to equipment performance (DF) will be discussed later in this report, there is only one direct and unambiguous way to measure it: off-gas effiluent samples have to be representatively collected and measured before and after each offgas treatment device. This is possible for all but the quench scrubber device, as remote sampling of the unquenched off-gas stream is not practical, due to high off-gas steam and aerosol loadings and the likelihood that the 
sampler will promote the growth of off-gas line blockages. The design of the samplers required to support equipment performance measurements is of course dependent upon the off-gas function of the device being characterized.

Elemental effluent losses associated with the LFCM process and supporting.plant activities are, with few exceptions $(H, C, B, N, S$, and the halogens), predominantiy associated with the emission of condensed-phase matter; i.e., aerosols (Goles, Mishima, and Schmidt 1989). Consequent7y, MOG and PVV systems designed to support LFCM plants are primarily composed of aerosol emission abatement equipment. This is true not only for the HWVP and DWPF plants currently under design but is also the case for the operating PAMELA facility in Mol, Belgium. Because of the similarities among these POG systems, it is not surprising that the process sampling systems designed to monitor in-cell equipment performance are primarily concerned with characterizing off-gas aerosol concentrations using sampling configurations similar to those illustrated in Figures 2 and 3 (HWVP $\mathrm{NO}_{x}$ and iodine emission abatement devices are exceptions to this statement). Due to the emphasis on aerosol abatement in LFCM off-gas systems, aerosol sampling requirements of a11 off-gas system aerosol abatement devices will be discussed together, after which iodine sampling requirements will be described. $\mathrm{NO}_{X}$ sampling requirements for SCR performance characterization have been previously evaluated in Section $\mathbf{2 . 3}$ of this report (Process Control).

\subsubsection{Aerosol Sampling}

In essentially all operating and planned LFCM vitrification facilities, in-cell aerosol samples are, or will be, collected by drawing process gas through sampling lines to shielded analytical cells or hoods where aerosol matter is collected on an absolute filter (see Figures 2 and 3 ). The filtered material is then analyzed off-line to establish elemental and/or isotopic off-gas concentration data. Beta-gamma counters are also used to continuously monitor radionuclide accumulations on (WVNS) and/or exiting from (DWPF, HWVP) POG HEPA filters. The HEPA accumulation monitor provides relative trend data that can be used directly to detect changes in HEPA aerosol collection rates, which in turn can be used with other related process data to alarm off-gas equipment malfunction conditions somewhere upstream of the HEPA filter. It is a primary purpose of the remote aerosol samplers to 
identify the device responsible for deteriorating off-gas system efficiency and to diagnose the nature of the malady.

The extent to which individual samplers can accomplish this task is totally dependent upon how representative the filter sample is to the conditions that exist at the sampling site. This, as discussed previously, depends upon where and how the sample gas is extracted and what transmission losses are sustained in transporting the sample to the aerosol filter. However, the importance of these criteria upon aerosol sampling results is strongly dependent upon the size distribution of aerosols present at the sampling site.

For aerosols having a mass median diameter $>1 \mu \mathrm{m}$; the generalized sampling criteria previously discussed must be strictly adhered to in order to preserve a representative sample stream. Unlike supermicron aerosols, particles <lim behave somewhat like a gas in that they are capable of following flow streamlines within a duct. Because of this unique aerodynamic behavior, submicron particle stratification within well-mixed duct flows will not occur, thus eliminating sample probe positioning requirements and the need for isokinesis (Sehmel 1973, 1970; Lundgren and Ca7vert 1967). Moreover, since depositional losses for submicron aerosols will be dominated by diffusional capture, transmission losses of these penetrating submicron aerosols should be quite low even under turbulent flow conditions. (a) As an example, depositional losses of $8 \%$ are estimated to occur for $0.3-\mu \mathrm{m}$ polydispersed aerosols being transported $-60 \mathrm{ft}$ through 1 -inch-diameter metal tubing.

From the above discussion it is clear that the adequacy of the reference DWPF aerosol samplers will depend upon the off-gas conditions being sampled, which is a site-specific variable. Thus, each off-gas aerosol sampling site will be individually discussed and evaluated as it relates to HWVP performance monitoring requirements.

(a) Sehmel 1970; Schwendiman, Stegen, and G7issmeyer 1975; Thomas 1973; Strom 1972 . 


\section{SBS Exhaust Site}

Quench scrubbers are low-efficiency devices specifically designed to condition the off-gas stream by cooling. it and removing supermicron aerosols. Resultant effluent aerosols penetrating these scrubbers are nominally found to be $\leq 2 \mathrm{~m}$ (Goles, Mishima, and Schmidt 1989). The mass median diameter of these aerosols, moreover, is a variable that is dependent upon processing conditions; as a result, representative sampling criteria need to be imposed at this sampling site if meaningful performance information is to be extracted. Unfortunately, the reference DWPF aerosol sampling system cannot satisfy any of these sampling requirements; i.e., the side port probe, which extracts sample gas at a $90^{\circ}$ angle to the process flow, cannot sample average conditions nor support isokinesis, and long extended sampling lines will resuit in high and variable aerosol deposition losses. The data collected from this site will therefore be of questionable significance unless the aerosol population being sampled is submicron, which it is not.

This conclusion has been experimentally corroborated by SRL evaluations of the DWPF reference aerosol sampling system (Figures 2 and 3) (Crow 1986; Guidotti et a1. 1987). Specifically, SRL found that, when applied to quench scrubber exhaust conditions, the reference sampler underestimated aerosol concentrations by as much as two orders of magnitude. Furthermore, the results obtained by the remote reference sampler were found to be totally nonreproducible. Similar results were obtained even when the entire run of sample line was heat traced. Moisture condensation in DWPF's unheated sample transport lines has led to additional concerns regarding the utility of aerosol data to be collected at other process sampling sites. The role of process aerosol sampling in support of the DWPF is therefore uncertain at this time. Apart from baseline data that will be collected at all sampling sites during startup, routine process aerosol sampling will, apparentiy, be used only to help perform equipment operational diagnostics on an as-needed basis. (a) This is not an unacceptable condition, since plant safety and operational permits do not rely on in-cell performance (DF) measurements of

(a) A. J. Lethco, Savannah River Plant, personal communication. 
aerosol emission abatement devices, as will be discussed later; however, it is fair to say that original design expectations of DWPF samplers have been somewhat revised.

From the above it is quite clear that remote process aerosol sampling techniques cannot be applied in a quantitative way to SBS exhaust stream characterization. Moreover, it is extremely doubtful that the DWPF aerosol sampling system would be at all useful in diagnosing a decreasing SBS scrubbing efficiency condition (channeling). This follows from the fact that loss of quench scrubber efficiency would primarily increase the concentration of 7arge-diameter aerosols that could not be efficiently extracted with the side port sampling probe nor transmitted through long sample line runs. As a result, the impact of large changes in off-gas aerosol characteristics might not always be observable at the aerosol sample collection site. This is not to say that SBS performance deterioration cannot be detected by using performance-related data, as will be discussed in Section 2.6.5. However, SBS channeling cannot be directly and unambiguously measured using the DWPF sampler configurations under all possible processing conditions.

The limitations of the reference sampling systems are so fundamentally linked to sample line lengths that no "quick fixes" can be applied to the existing system. What is needed is a remote detection system, located at the SBS off-gas sampling point, that could monitor off-gas conditions much like the WVNS in-cell HEPA monitoring device previously described. Such a device would significantly improve the reproducibility and usefuiness of off-gas effluent information by minimizing the major sources of off-gas sampling error. Because of its potential benefit to the HWV, the functional design features of a remote off-gas aerosol detection system are described in the appendix to this report.

The above remarks are pertinent to only the MOG SBS, as PVV SBS influent aerosols will be submicron and highly penetrating under most conditions (Goles, Mishima, and Schmidt 1989). However, because of the water loadings characteristic of SBS exhaust streams, al1 sample transmission piping needs to be heat traced in order to minimize aerosol growth and subsequent transmission line losses. Particulate PVV SBS samples collected with the 
reference DWPF sampler configuration will be much more diagnostically useful than corresponding MOG samples, whether heat tracing is used or not.

\section{HEME Exhaust Site}

A high-efficiency mist eliminator (HEME) is used in the HWVP melter offgas processing system as a deep-bed washable filter for high-efficiency removal of process-generated aerosols. Like HEPA filters, the HEME capture efficiency tends toward unity for particles $\leq 0.03 \mu \mathrm{m}$ and $\geq 0.5 \mu \mathrm{m}$; as a result, the spectrum of aerosols penetrating a weli-performing HEME (or HEPA) will be characterized by a mass median diameter between $0.1 \mu \mathrm{m}$ and $0.3 \mu \mathrm{m}$ (Fuchs 1964; Dyment 1963; Stafford and Ettinger 1971; Kirchner et a1. 1984). This has been recently confirmed during pilot-scale testing of the HWVP MOG processing system (Goles et a]. 1989). From previous discussions concerning submicron sampling criteria, the reference aerosol sampling system should be expected to provide useful monitoring data at this and all downstream sampling sites under normal conditions. However, the low transmission loss rates in sample transport tubes previously discussed $(<10 \%)$ were for ideal conditions that did not include influences from condensed-phase water.

For the HWVP, condensation will almost certainly occur in sample stream transport lines, as their temperature will be at or below the dew point (SBS quench temperature) of the process exhaust. Sample line condensation will not only wet sample line walls but will produce a mist of submicron water aerosols in the sample stream. This saturation condition will promote growth of the primarily soluble. aerosols being conveyed to the aerosol filtration device (Calvert and Jhaveri 1974): This, in turn, will produce greater than expected transport losses, the magnitude of which is difficult to predict a priori. Because transport losses will be a variable function of processing and cell temperature conditions, an inconstant and unpredictable sample bias can and will yield variable sampling data. To ensure the representativeness and the usefulness of the HEME aerosol sampling data, condensation within sample transport lines must not be allowed to occur; thus, heat tracing the entire sample line run, right up to and including the aerosol collection device, will be necessary.

If the reference aerosol sampling system (Figure 3 ) is modified to include sample line heat tracing, the information provided by the reference 
sampling system will still be fundamentally limited by sample line length as it was for the SBS sampling site. This is because sample line deposition. loss (sample bias) is functionally dependent on the mass median diameter of the aerosol population being transmitted. If HEME performance deteriorates, the aerosol size distribution of exhausted aerosols will no doubt shift to include larger particles. However, the influence of these larger diameter particles upon the filter catch will be diminished by sample extraction bias and enhanced line losses. The degree to which this information is damped will depend upon the degree to which the aerosol distribution has shifted. Thus, the greater the off-gas problem, the lower will be the response function of the sampling and detection system.

Representativeness therefore cannot be ensured merely by heat tracing sampler transport lines. There is no doubt that the traced or untraced sampling system illustrated in Figure 3 would respond to changes in aerosol concentrations at the HEME site and would, consequently, be of considerable value as a process diagnostic tool, as will be discussed in Section 2.6. The dilemma is that data collected could not be specifically used to establish the nature of the changes that had occurred, nor could DFs be established. This is precisely why the development of a close-coupled remote off-gas aerosol sampler (discussed in the appendix) offers an attractive alternative for monitoring HWVP off-gas processing conditions.

\section{HEPA Sampling Sites}

Dual (parallel) tandem HEPA filter assemblies are used as the final aerosol treatment devices for HWVP off-gas process streams before release from the remote process cells. These high-efficiency polishing filters are responsible for a high proportion of the total aerosol decontamination factor (DF) associated with both PVV and MOG treatment systems. The normal process sampling conditions at all three HEPA (two MOG and one PVV) sites are essentially equivalent to those previously described for the HEME sites. Consequently, some conclusions regarding the adequacy of the reference sampler configuration for the HEME sites will also pertain to the HEPA sampling points.

Specifically, the need to heat trace sample lines is as important for HEPA sampling systems as it is for the HEME sampler. However, the 
limitations associated with HEPA sampling data are not as severe as those described for the HEME. For instance, the heat-traced modified sampler illustrated in Figure 3 will be extremely sensitive to performance deterioration of the upstream HEPA, since filter influent aerosols will be primarily submicron. As a result, a deteriorating HEPA filter would be expected to increase aerosol concentrations while not significantly affecting the size distribution of these aerosols. Thus, the resultant off-gas changes would not significantly affect sampling bias, and sample data variations could be directly related to changes occurring at the sampling point. These remarks assume that performance deterioration of the MOG HEME is not simultaneousiy occurring, as the combined effects of these conditions would

- change the mass median diameter of sample site aerosols: Under reference HEME operating conditions, the DWPF sampler data could be used to directly measure process HEPA assembly DF. Since the HEPA exhaust is heated, in-cell tracing of HEPA sample lines may not be necessary if their lengths are minimized by running the lines through the contact-maintained area of the plant. Plant design is not at a stage where a decision on this issue can be made. In any event, the sample delivery and/or sample collection devices located in this radiation control zone would have to be heated.

\section{Aerosol Sampler Summary}

The applicability of reference aerosol sampling systems to TDP requirements for performance monitoring of off-gas treatment devices has been evaluated. Heat tracing sampling lines to reduce sample line losses has been found to be a general requirement at essentially all sampling locations except possibiy the HEPA site. However, heat tracing is not a sufficient condition for providing representative sampling data. The size distribution of aerosols, which is a sampling site-dependent parameter, is the most influential factor affecting the representativeness of samples collected through long sample delivery lines. Because of this, sampling data collected from the SBS exhaust are expected to be so compromised by sample line deposition losses that their utility, except for qualitative diagnostic purposes, will be severely limited. HEME and HEPA sampling data, on the other hand, should definitely provide useful, performance-related, diagnostic information with or without heat tracing; however, the reproducibility and value of the 
resultant off-gas sampling data obtained will be significantly improved if heat tracing is employed. HEPA filters were the only devices for which the reference samplers could possibly provide a direct indication of performance (DF), but this could only be accomplished under standard HEME operational conditions.

In general, the usefulness of process aerosol samples was found to be fundamentaliy limited by long sample transport lines connecting the remote sample site with the local effluent sampler. Since it is not reasonable to construct the HWVP around a sample line length constraint, remote monitoring systems located at off-gas sampling points offer a viable alternative for significantly improving the value of off-gas effluent information. This type of device will minimize the major source of off-gas sampling error that plagues the reference design (transport losses), while providing nearcontinuous monitoring of off-gas system aerosol loadings.

Although remote off-gas monitoring techniques will provide only a relative measure of radioactive effluent concentrations without the benefit of elemental composition, there is little need for this additional information; the most sensitive indicator of aerosol abatement performance is the transmittance of submicron particulate matter (Goles and Andersen 1986).

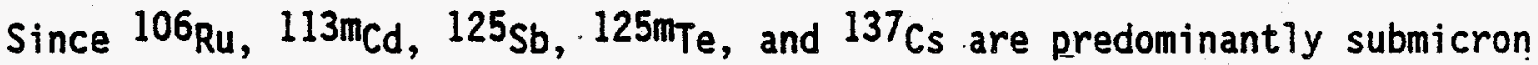
aerosol effluents that will be major contributors to the specific activity of off-gas aerosols (Goles and Andersen 1986), measuring radioactive effluent off-gas concentrations is the most direct way to monitor off-gas system performance. In fact, an on-line monitoring system can provide continuous surveillance capabilities that are not supported by conventional batch sampling techniques.

Unfortunately, systems designed to accomplish the remote monitoring task are nonexistent, al though the functional components from which such a system can be fabricated are commercially available. Thus remote, real-time off-gas monitors supporting the HWVP operations can, in principle, be developed through use of existing technologies, but a significant design, development, and testing effort would be required to qualify and implement such a system. However, such a system not only promises to provide more and higherquality off-gas data at less cost, but should also significantly reduce plant 
personnel exposure rates. Because of the operational advantages afforded by remote-monitoring techniques, a functional description of a generalized remote off-gas process monitor is briefly discussed in the appendix.

\subsubsection{Iodine Sampling}

The last off-gas component that needs to be discussed relative to HWVP performance monitoring requirements is the MOG iodine scrubber. This device, assumed to be a silver mordenite sorption trap, is ciesigned to abate gasphase emissions of iodine. Since iodine off-gas effluent will be predominantly in the gaseous state, sample representativeness (as with $\mathrm{H}_{2}, \mathrm{CO}$, and $\mathrm{NO}_{\mathrm{x}}$ ) will be primarily influenced by transmission losses in sample delivery. lines. Deposition studies have shown ordinary carbon and stainless steel sampling lines to have a high affinity for elemental iodine, which can cause significant sample bias--especially under high humidity (Kabat 1982; Unrein et al. 1984). Aluminum sample lines possess much better iodine transmission characteristics under all moisture conditions, although significantly less deposition occurs. at low humidity.

To minimize iodine sample bias, as required by the TDP, replaceable sample delivery line segments should be constructed of aluminum, if possible, and the entire sampling line run must be heat traced up to the iodine sample collection device (charcoal). To preclude sample losses from a reactive filter media, only pure glass fiber filters should be used to prefilter the sample stream before iodine collection (Kabat 1982). Furthermore, because iodine sample line losses are residence-time dependent, sampler flow rates should be as high as practical. Since high flow rate (turbulent) conditions are not necessarily compatible with optimal aerosol collection, a separate sampling site should be considered for each effluent class if record samples are to be collected for both. Ideally, the HEPA and subsequent SCR heater sites would be used exclusively for particulate and iodine sampling, respectively. Under normal processing conditions, the final HEPA sampling site is suitable for both aerosol and jodine sample collection, provided a filter medium is used that is compatible with all aerosol analysis strategies and is chemically inert to gaseous iodine effluents. The above sampling considerations need to be equaliy applied to the post-iodine sorber sampling site, as both samples are required to directly measure iodine emission 
abatement performance; however, unlike the HEPA sample location, analys is of the particulate sample fraction is not required at this site since the iodine abatement device is not credited with, nor does it deserve, an aerosol DF.

As with most previous evaluations, the reference sampling system illustrated in Figure 3 needs to modified to allow sample transport lines to be heat traced right up to the iodine collection device to meet representative sampling requirements. If the post-heater sampling site is used to support iodine performance measurements as discussed above, in-cell sample line conditioning requirements can perhaps be relaxed due to high sample gas temperatures and the proximity of the contact-maintained area to the iodine bed. To minimize sample transport line losses, as much of the sample delivery line as possible should be constructed of aluminum.

\subsection{WASTE FORM QUALIFICATION}

As discussed previously, remote sampling of the unquenched MOG stream is not operationally practical, due to the high steam and aerosol loadings in the unquenched-melter exhaust and the potential for sampler-induced jumper blockages. Therefore, in-cell off-gas sampling cannot directly measure melter losses nor verify waste form qualification models. To estimate MOG losses, representative liquid sampling techniques need to be applied to the quench scrubber (SBS inner) tank. Since $>90 \%$ of melter (condensible) losses are collected by the quench scrubber (Goles et al. 1989), scrub liquor eff7uent accumulation rates are of major importance in establishing an overal1 melter mass balance. Except for the semivolatiles, quenched off-gas effluent data should have little influence upon the melter mass balance and, therefore, upon the waste form qualification model. If in-cell off-gas data are required for model verification, major changes to the presently designed quench scrubber exhaust sampler need to be implemented to address sample representativeness issues: 


\subsection{OPERATIONAL OIAGNOSTICS}

A7though not explicitly mentioned in the HWVP FDC or TDP, process offgas samplers also need to provide operational diagnostic information to the plant engineering staff. This has been previously mentioned in discussions of HWVP performance monitoring requirements, where it was stated that while reference off-gas samplers might not be capable of supporting direct performance (DF) measurements, they would, nevertheless, be quite useful in monitoring for changes in off-gas stream conditions that resulted from equipment performance variations. Although this performance related data could not, of and by itself, define the cause or nature of observed off-gas changes, it could, nevertheless, be correlated with other off-gas data to do just that. For example, an increase in HEME exhaust sampling results could mean a failure of the HEME element, or it could be related to a deteriorating SBS scrubbing efficiency. The liquid composition of the SBS scrubbing liquor (and HEME waste stream if available) combined with tank and exhaust temperatures could be used with HEME aerosol compositional and $\triangle P$ data to conclusively resolve the nature of this operational malady.

Beyond performance monitoring support, the reference off-gas samplers can, in conjunction with other process parameters, help identify unstable LFCM processing conditions, detect overfeeding and/or the onset of melter bridging, and locate and/or measure melter and off-gas system inleakage sources. The ways in which off-gas data can be combined to diagnose common operational difficulties and/or failure modes are summarized in Table 1 along with recommended operational responses. This tabular information will be briefly discussed below.

\subsubsection{Melter-SBS Off-Gas Jumper Blockage}

If a restriction forms in the off-gas jumper between the melter and the SBS, the most significant physical sign of its presence is an unstable melter vacuum with no concurrent changes in noncondensible flow rate or equipment pressure drop. Pressure and flow transducers are the only devices that can be effectively used to diagnose this off-gas problem, and POG samplers are of no use whatsoever. The only adequate solution to this off-gas 


\section{IABLE 1. LFCM Process Fatlure Mode Identification and Problem Rectification}

\section{EAILURE MOOE/CONDITION}

Mel ter-sBS Jumper Blockage

Melter cold Cep Bridging

Unstable Processin Conditions

Excessive Inleakage (corroded off-gas

\section{PHYSICAL MAMIFESTATIOUS OF FAILLRE}

The variability in mel ter plenum vecum increases in trequency and magni tude. No concurrent changes in off-gas flou rate or equipment pressure drops.

Definite changes in melter glass temperature profiles. Possible decreased feed normalized $\omega_{x}$ emission rates, especial ly without $t$ id heaters. $\mathrm{CO}_{x}$ to $10_{X}$ emiesion rates will increase.

Glass temperature proflles will change. Large variebillity in off-gas concentrations of the volatile axides of carbon and nitrogen. Increased concentrations of nomvolatile feed components in SBS scrubbing fluid.

ncrease MOG flou rate, inability to control melter vacum, increased equipment pressure drop, decreased $\mathrm{No}_{\mathrm{O}}$ equipment pressure drop, decreased $\mathrm{MO}_{\mathrm{x}}$
and $\mathrm{co}_{\mathrm{x}}$ concentrations, and decreased equipment performance.
Deteriorating SBS Performance

Deteriorating HEME Performance

Deteriorating HEPA Performance

Deteriorating lodine Bed

Deteriorating $\mathrm{HO}_{\mathrm{x}} \mathrm{SCR}$ Scrubber
Increased HOG werosol concentration, increased quenched off-gas temperature, possible increases in HEME aqueous waste streen losdings, possible increases in HEME equoous maste strean flow rate, decreased SBS fluid temperature and effluent collection rates.

Increased wos aerosol concentrations, increases in MEPA accumlation rates, increases in MEPA accumulation rates, MEPA pressure drop, decreased HEME Cs collection rates.

Increased HOG aerosol concentrations, possible decreased pressure drop.

Increased woG concentrations of 129 (decreased iodine of).

Decreasing efficiency at fixed $\mathrm{HH}_{3}: \mathrm{HO}_{2}$. changes in bed temperature profiles and increased $\mathrm{MH}_{3}$ effluent concentrations.

\section{REQUIRED DIAGMOSTIC EOUIPNENT}

Mel ter plenum and off-ges symtem pressure treneducers and off-gas system flow rate menuring device(s).

Melter glase and plenum thermocouples, process gas sampler and on line $\mathrm{HO}_{\mathrm{X}}$ and $\mathrm{CO}_{\mathrm{x}}$

Melter thermocouples, off-gas sampler with $\mathrm{m}_{x}$ and $\mathrm{CO}_{\mathrm{x}}$ analyzers, sas liquid sempler.

Flow transducer(s), pressure transducers, offgas cemplers, gas analyzers
REMEDIAL ACUIONS REQUIRED

Terainate feedino, suitch to ausilliary MOG system, remove MOG jumper, find and remove blockage.

Jerminate feeding allow cold cap to partidlly burn away.

Decrease feeding rate to llow cold cep to redistribute itself and then louly raup up to the reference rate.

Use flow and pressure transducer data or off-ges samplers and/or gas data or off-gas samplers and/or location. Test flanges, and nozzle location. Test flanges, and nozzle covers and if necessary ident ify leaking component using a tracer gas and off-gas sempler/gas analysis system. Replace or repair failed part.

SBS exhoust and tenk thermocouples, MEME and SBS liquild samplers, sBS off-gas aerosol sempler, HERE and SBS aqueous drain rate manitors.

Remove SBS bed. Examine the distribution plate and the inner tank for collids bulldep and or fouling. If none replace the bed otherwise remove foreign matter.

Off-gas particulate samplers, MEME and HEPA radiation monitor, pressure transducers. HEME liquid seapler.

Off-gas aerosol radiation monitor, process aerosol samplers, and pressure transducers.

Process off-gas samplers.

Process oft-gas samplers, MO monitors, catalytic bed thermocouples, and $\mathrm{NH}_{3}$ moni tor.
Exemine and replace HEME filter elements as necessary.

Change out filter assembly then failure influences post HEPA MOO redionucl ide concentrations.

Change out bed when abatement efficiency begins to decrease.

Maintain operating efficiency by increasing $\mathrm{HH}_{3}: \mathrm{HO}_{\mathrm{X}}$ ratio unt it $\mathrm{HH}_{3}$ change out catalytic bed. 
problem is to disassemble the jumper and remove the restricting deposits that may be at the entrance to the film cooler, within the jumper itself, or in the SBS downcomer.

\subsubsection{Melter Bridging}

When the melter cold cap begins to bridge the glass surface, temperature profiles within the melter will become unstable. The glass surface temperatures will rise and plenum temperatures around the cold cap will decrease if auxiliary plenum heaters are not employed (which is assumed to be the case): Feed-normalized emission rates of $\mathrm{NO}_{x}$ will decrease and $\mathrm{CO}_{x}: \mathrm{NO}_{x}$ ratios should increase. Off-gas sampler data combined with melter temperature trends may be useful in identifying an impending bridging condition before it occurs. The specific sampling site selected is of no importance, as long as it is upstream of the variable melter control air injection source. Terminating or drastically reducing melter feeding rates to reduce cold cap size is the only remedial action required to resolve this processing problem.

\subsubsection{Unstable Processing Conditions}

Unstable melter processing conditions are punctuated by increased feed entrainment losses. This will significantly increase the off-gas loading and mass median diameter of melter-generated aerosols. Process aerosols samplers will not be capable of characterizing this situation due to high SBS abatement efficiencies and low sampler transmission efficiency for entrained matter. However, process gas sampler data from any quench scrubber exhaust site can be effectively used to detect the onset of processing instabilities, as melter gas generation rates $\left(\mathrm{CO}_{x}\right.$ and $\left.\mathrm{NO}_{\mathrm{x}}\right)$ become highly erratic under these conditions. An unstable melter glass temperature profile is also a good indicator of nonsteady-state processing conditions. Although slow to respond, SBS scrubbing liquor composition can also be used with feed compositional data to estimate melter DFs. To restore melter stability and performance, the melter feeding rate should be decreased to reduce and redistribute cold cap coverage, after which feeding can be slowly ramped up to the reference rate. 


\subsubsection{Excessive Inleakage}

Melter and/or off-gas line leaks produce increased noncondensible offgas fiow rates that can increase MOG equipment pressure drops, decrease equipment performance, and reduce off-gas concentrations of the volatile oxides of nitrogen and carbon. By monitoring equipment $\triangle \mathrm{PS}$ and/or process sampler effluent gas concentrations as a function of off-gas location, the source of inleakage can be localized. The exact inleakage source can be further isolated by monitoring downstream off-gas composition while flooding specific off-gas sites with a tracer gas. If the meiter is the source of inleakage, off-gas system temperatures may also be affected, depending upon the magnitude of the leak. Process samplers can also be used in conjunction with a plenum-injected tracer gas to measure the magnitude of melter inleakage by gas dilution techniques. Similarly, sampler piping can be used to inject tracer gases into selected off-gas system locations to help identify leaking off-gas system components. Once the leaking component has been found, it can be fixed or replaced as necessary.

\subsubsection{Deteriorating SBS Performance}

The SBS is a quench scrubber that cools the POG stream and provides lowefficiency aerosol removal capabilities. Channeling, the most probable MOG SBS failure mode, will cause a deterioration in both of these off-gas processing functions. As a result, quenched off-gas aerosol and water loadings would increase along with off-gas temperature, should such a failure occur. Correspondingly, the SBS scrubbing fluid temperature would be expected to decrease while the mass flow rate of effluents in the HEME's aqueous waste stream would increase. Because of the high sample line transport losses associated with unmodified melter aerosols, the impact of channeling may not significantly influence process sampling aerosol data. Since both steam and aerosol recoveries are reduced by channeling, SBS scrubbing fluid composition may not be a good indicator of performance either, although SBS mass collection rates of effluents (volumetric steam collection rate $x$ concentration) would be.

Unlike the MOG SBS, the influent conditions of the PVV device will, under all anticipated processing conditions, be primarily composed of airborne, submicron particulate matter. Consequently, the reference DWPF 
sampler configurations should be useful in detecting changes in SBS performance by simply measuring radioactive aerosol concentrations in conjunction with other process variables. This is indeed fortunate, as there are no secondary waste streams in the PWV related to SBS performance.

SBS channeling can be caused by scrub tank solids accumulation and distribution plate and/or bed fouling. In any case, the SBS bed would have to be removed to identify the physical cause(s) of the observed malfunction before the condition could be rectified. Fouling of the bed and/or distribution plate is easily remedied by replacement of the bed itself. Remote removal of sedimented tank deposits might prove difficult unless this contingency is $p 7$ anned and designed for.

\subsubsection{Deteriorating HEME Performance}

The HWVP uses process HEMEs as high-efficiency, deep-bed washable filters that are designed to remove submicron aerosols--both liquid and solid. Consequently, increases in off-gas aerosol loadings, in the absence of SBS problems, would be the most direct indicator of HEME performance deterioration. Because of the high characteristic HEME DFs for submicron aerosol, major changes in HEME performance will be observable using reference (DWPF) aerosol sampler data. Sampler response sensitivity to changes in HEME DFs will be enhanced by heat tracing the sample delivery line, but in general, HEME aerosol samples will never qualify as being representative, with or without heat tracing (see Section 2.4, Equipment Performance). Other process indicators of a deteriorating HEME include increasing HEPA pressure drop over long period of time, a possible decrease in HEME pressure drop, and a possible decrease in HEME aqueous drain rate. Of these indicators, off-gas sampling data will provide the most sensitive means of detecting HEME DF deterioration. Once deterioration is detected, the only course of remedial action is to switch to the backup HEME/HEPA system and replace the failed HEME's filter elements.

\subsubsection{Deteriorating HEPA Performance}

Degradation in HEPA performance wi11, in the absence of concurrent HEME problems, be directly indicated by increases in post-HEPA concentrations of (radioactive) aerosols. Reference POG aerosol samplers and continuous $\beta^{-}-\gamma$ off-gas monitors are the most effective means of detecting such an event. 
Indeed, under reference HEME operating conditions, POG samplers can be used to directly establish HEPA assembly DFs, provided that sample line heat tracing is employed at both sites. HEPA pressure drop is the only other process indicator of filter breakthrough, al though it is not a very sensitive one. The onty process response to degraded HEPA assembly performance is to replace the entire HEPA assembly.

\subsubsection{Deteriorating ${ }^{129}{ }_{1}$ Trap}

Reference process sampler data obtained from the iodine trap effluent stream can be directly used to diagnose decreasing ${ }^{129}$ I trapping efficiency if heat tracing is employed. Without heat tracing to preclude moisture condensation, the sample line itself will become an iodine effluent source that can overwhelm the off-gas source, especially after a failed trap has been replaced. No other process parameters or measurements can provide additional or complementary performance-related information about this device. Replacement is the only remedy for a failed iodine trap.

\subsubsection{Deteriorating NO $\times$ Scrubber}

Representative sampling in support of the SCR operations is necessitated by plant process control requirements and is readily achieved by reference plant samplers with heat-traced sample delivery lines, as previously discussed. Consequently, the performance of the SCR device at a fixed $\mathrm{NH}_{3}: \mathrm{NO}_{\mathbf{x}}$ ratio will be continuously monitored by routine plant operations. Other. indicators of degraded SCR performance include increased bed emissions of $\mathrm{NH}_{3}$ and changes in the temperature profiles across the SCR catalytic bed due to reaction zone migration. Since SCR NO$x$ destruction efficiency is a function of $\mathrm{NH}_{3}: \mathrm{NO}_{x}$ ratio, efficiency can be maintained by increasing this set point ratio. Because this will also increase the residual concentration of $\mathrm{NH}_{3}$ effluent, a limit to acceptable ratios will ultimately be reached at which point the catalytic bed will have to be replaced. 


\subsection{PROCESS ENGINEERING OFF-GAS MONITORING NEEDS}

The process sampling criteria set forth in the HWVP TDP guarantee that complete and unambiguous off-gas processing information will be available to the plant engineering staff so that informed decisions can be made about the operation and maintenance of the HWV's off-gas system. As previous discussions have shown, the representativeness criterion imposed upon process samples cannot be achieved using the DWPF sampler designs except in a very few but important instances. However, as the discussion of HWVP operational diagnostics needs (Section 2.6) revealed, performance-related off-gas data can be effectively used with other related process parameters to arrive at the same conclusions that could be directly derived using representative data. Although diagnostic data are semi-quantitative or even qualitative in nature, they can, nevertheless, be effectively used to make process-related decisions. The main drawback to basing process decisions on diagnostic data is that all conclusions will be based upon multi-variant data correlations, which can be ambiguous. Since the only binding requirements involving $p$ ant operations are those that ensure plant safety and permit compliance, some off-gas system operations could be based on diagnostic sampling data if the TDP were appropriately amended. This section discusses the minimum process sampling requirements needed to provide necessary $\mathrm{plant}$ operational data.

From a process engineering standpoint, sampling data will be needed to ensure process safety, to control equipment operations, to maximize process efficiency, to monitor off-gas equipment efficiency, and to identify the source of off-gas system problems or malfunctions. Each of these operational needs will be discussed separately in terms of necessary sampling sites, the data needed from these sites, and the adequacy of the DWPF sampling system to provide these data.

\subsection{MONITORING FOR SAFETY}

Engineering sampling needs for combustibility monitoring cannot be any less rigorous than those previously established by HWVP TDP requirements. The sample must be representative, and it has to be taken from the off-gas stream exhausting the SBS quench scrubber to avoid deleterious dilution 
impacts upon instrument sensitivity and measurement accuracy. At the present stage of off-gas design the PVV will not use post-SBS vacuum control air injection; as a result, PVV LEL monitoring can be safely conducted at the PVV HEPA exhaust, which will simplify sample conditioning requirements. The DWPF reference sampler design was found to adequately satisfy combustibility monitoring needs, provided the portion of the total sampler flow (slip stream) directed to the LELs is maintained clean and dry.

Residual $\mathrm{NH}_{3}$ concentrations in the exhaust of the SCR also need to be representatively monitored to preclude formation of hazardous $\mathrm{NH}_{4} \mathrm{NO}_{3}$. Reference DWPF sampler design can support this requirement so long as heat tracing is employed, although $\mathrm{NH}_{3}$ samplers and/or monitors can be sited locally as the SCR is located in a contact-maintained area.

\subsection{MONITORING TO CONTROL OFF-GAS EQUIPMENT}

The only off-gas system device needing sampler-based control is the SCR. Engineering sampling criteria to control this device cannot be any less rigorous than those previously established on the basis of TDP requirements (see Section 2.3, Process Control). A representative $\mathrm{NO}_{x}$ sample must be extracted from the combined MOG and PVV off-gas stream entering the device. The remote reference DWPF sampler design can support this requirement as long as sampler lines are heat traced. However, the $\mathrm{NO}_{x}$ sampler/monitor need not be remote from the SCR since this device is located in a contact-maintained area.

The same criteria for monitoring the SCR influent concentrations of $\mathrm{NO}_{X}$ must also be applied to the SCR's exhaust, as the SCR's control set point depends upon destruction efficiency, which is dependent upon whether representative data are being collected at this site. The conditions previously established for $\mathrm{NH}_{3}$ monitoring apply equally well to $\mathrm{NO}_{X}$, so both requirements can be satisfied with one sampling site and a single sampler design.

\subsection{MONITORING PROCESS EFFICIENCY}

An important factor in optimizing or maintaining process efficiency is melter DF. As discussed previously, direct sampling of the unquenched melter exhaust is not a practical process sampling goal because of the high steam 
and aerosol loadings encountered there and the fact that sampling probes will produce off-gas line blockages and concomitant process disruptions. Melter efficiency can, however, be derived from measurements of effluent conceritrations in SBS scrubbing liquor when combined with steam collection rates (overflow rates) and average feed compositional data. Since representative sampling of these liquid streams will be required to support waste form qualification models (see Section 2.5, Waste Form Qualification), the need for MOG sampling data will be satisfied by process liquid sampling requirements provided that SBS overflow rates are monitored. The above conclusion assumes that the SBS is operating normally, which of course has to be verified by SBS performance-related data, identified in Table 1 and discussed below.

\subsection{MONITORING OFF-GAS EQUIPMENT BEHAVIOR}

Performance-related information is needed by the process engineer to run and efficiently maintain the HWVP off-gas system. The subject of operational diagnostics has been thoroughly discussed in Section 2.6 and the results of this discussion are summarized in Table 1. The tabular data identify key indicators needed to qualitatively monitor equipment performance. The type, nature, and source of process samples required to support semi-quantitative performance monitoring will be discussed for all POG equipment.

\subsubsection{Submerged-Bed Scrubber}

Increased radioactive aerosol concentrations in the SBS exhaust are the best indicator of performance deterioration, if accompanied by decreased SBS steam collection and other process indicators listed in Table 1. As previous discussions have shown, reference samplers are totally inadequate for sampling the SBS exhaust and local radioactive aerosol monitoring capabilities are totaliy unproven. Thus the best indicator of SBS performance wouTd be the mass flow rate of ${ }^{137}$ Cs (or other solubre activity) in the HEME's aqueous waste stream. To obtain this information, HEME aqueous concentrations and drain rates must be measured. This is not currently planned. Since, in general, no other process sample can provide semi-quantitative information on SBS performance, provisions should be made to add this liquid sampling capability to the HWVP off-gas system design. 


\subsubsection{HEME and HEPA}

Monitoring the ${ }^{137}$ Cs concentrations in the exhausts of these two devices is the most sensitive indicator of performance deterioration, as long as the variability in influent conditions can be appropriately accounted for. DWPF samplers will be responsive to major changes in filtration efficiency by either of these devices. Sensitivity of this monitoring approach has to be empirically determined at each site, as the influence of moisture on sample transmission efficiency is difficult to predict a priori. Since ${ }^{137} \mathrm{Cs}$ is a key, indicator of performance at both sites, for reasons that have been previously developed and explained, the accumulation rate of cesium activity on HEME and HEPA filter samples should be continuously monitored to improve the sampler's response time to off-normal conditions.

\subsubsection{Iodine Trap}

To monitor iodine abatement performance, the iodine trap's ${ }^{129}$ I effluent stream must be monitored. If heat tracing is added to the DWPF sampler design, useful diagnostic information can be obtained if the influent source does not change. Because off-gas line components can accumulate and become iodine sources, sampling of influent conditions may become necessary to verify deteriorating performance; i.e., to measure DF. In-cell sample conditioning requirements can be significantly simplified if the iodine sample lines are run directly to the adjacent contact-maintained area, as the sample stream temperatures will be quite high $\left(-200^{\circ} \mathrm{C}\right)$.

\subsubsection{Selective Catalytic Reducer}

SCR operational efficiency has to be monitored for process control purposes, representative samples of $\mathrm{NO}_{x}$ will therefore be collected from the device's influent and effluent streams. Reference sampler design was found to be adequate for this purpose provided that sample delivery lines are heat traced. $\mathrm{NO}_{\mathrm{x}}$ sample/monitoring equipment need not be remotely located, as the SCR is in a contact-maintained area in the plant; however, the upkeep of heat traced lines in a contact maintained area is probably easier than and preferable to supporting sampling instrumentation in a controlled radiation zone. 


\subsection{MONITORING TO IDENTIFY OFF-GAS SYSTEM PROBLEMS}

Sampling lines supported by reference samplers need to be run to the exhaust ports of all remote equipment to allow sufficient flexibility in identifying off-gas problems or diagnosing processing difficulties such as those previously discussed and summarized in Table 1. This would in reality add only three sites to those already specified, and 211 of these are associated with POG HEPA heaters. These additional sites would also provide backup to the important HEPA influent sampling locations.

\subsection{OFF-GAS SAMPLING NEEDS AND REQUIREMENTS}

A comparison needs to be drawn between fundamental engineering needs for process sampling and process samples required by the HWVP TDP. Table 2 summarizes the information provided in this and the preceding section of this report. Operational support in the process monitoring area is the only major area where these assessments differ, and these differences are significant. Specifical1y, TDP-based performance monitoring requirements for the aerosol abatement equipment are unachievable using DWPF sampler configurations. Performance-related information to satisfy plant operational needs can, however, be extracted from this standard sampler configuration for essentially all sampling sites. The quench scrubber (SBS) exhaust sampling site may be an exception to this statement based on DWPF simulation tests that have been discussed. As a result, HEME aqueous waste stream monitoring is the method of choice for providing these operationally important data. Since particulate (filter) samples will have to be collected from the SBS site to support off-gas flammability (LEL) monitoring requirements, these qualitative data will also be available for process diagnostic purposes.

Heat tracing is considered to be important for ${ }^{129} \mathrm{I}, \mathrm{NO}_{\mathrm{x}}$, and $\mathrm{NH}_{3}$ sample collection even for operational engineering purposes. Because the affected sampling sites are downstream of off-gas heaters and will be near or part of a contact-maintained area, the difficulties associated with heat tracing these remote sample lines will be somewhat mitigated. Since the SCR itself is located in a contact-maintained area, the option of locating the $\mathrm{NO}_{\mathrm{X}}$ and $\mathrm{NH}_{3}$ sampling equipment at the SCR sampling sites is a feasible one. Alternatively, this equipment could be conveniently located out of the radiation 


\section{TABLE 2. Comparison of HWVP Process Sampling Requirements and Process Operational Sampling Needs}

\author{
pypeose of sumes: \\ Sefec: \\ flamibitity: \\ Explosive Haxards \\ (intillogl)

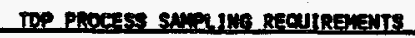 \\ Representasive stapling for $H_{2}$ and 60 ; \\ Referense ave septer desion adnote. \\ heat erweing of min smple trenopert \\ IIne are noe required. StIp streen \\ fewding lats met be elem (ffttered) and

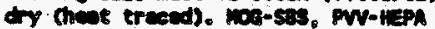 \\ Repreantative senpline and/or monitorin \\ of the ser exhwist for Mils. ONPF \\ seplers deaters adequete but all semple \\ tremeport II ines wint be heat troesd. \\ semplerfinint tor cen be lacated loestly in \\ contest mintelined selt
}

\section{Proces: Control}

sen centrol:

Perforwan weaterin:

Metter:

Sos:

nath:

KePA:

129 trap $4 \operatorname{sen}$

Heste form

oulification

gorational Diognestic:
Repreanthel ive sempling of sch influent and offlume strecm for mox $^{\circ}$ Reference oup septer devion edponte if all enple ditivery lime ore heat traced Leed sitin of sapler/mont tor in contect mintained ares is a semplin. confiaretion ol ternetive.

Process off-ges scipting of unpunched

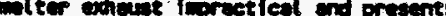
a enceeptable off-gas line blockese thrent. We provisters for.

Repreantative sulin of ses exhant for esresols. Dipf referwe septers indeques with or withous heot treing. in-edt suple collestion and out of eat ontrofs finprectical. Alternetive in call off-ses aerosol monitoring syoten uproven. Nen techolosy required to entiste reotirent.

Repreasentaciv sapling of Inftume and efflumt astosol cencentrations. Reterence sempler design edaquece only for extumet semple under normal procensirs condition if all sempte transerte tince are hene trueed. In generel saples eamot be considered representeativ with of without homet trosing.

Repreachetive sapl ing of inf tumt and efftume aresol concentrat fors. Reterenes sopler chation with hest Referance sapler design with heat and is indequte for the influent soures exeape under normal off-gat conditione.

Representative sespling of igftume and offluent cancentrations of $\mathrm{CS}_{\mathrm{l}}$ and $\mathrm{mo}$. respectivaly. Reference semplers adeatite respectivaly. Reference sesplers but mitoring for $10 \mathrm{~g}$ la poselble.

Sanpling of the unamehed net ter exhoust is not suportable by direct off-gas sumpl In. Representative supling of the ses seubbing liabr and meenurenent of steen collection rates is nouded to setisfy this requiresent.

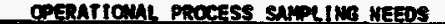

Som top requirements.

sem to reasiramente.

som rop supt in paquirenents

Represuntative sepling of the ses seubbing liques and neweurewint of stean collection raten. This thte mor elso be necengery for saporting wate for quilficetion modis.

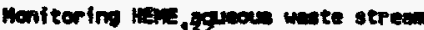
cencentrattens 137 Cs and wesuring equeous drain rate. other related process peraneters which wine atso be trecked are ses fluid and exhouse temperaturea, stas and hane woter. collection raten.

Honitoring off-gas conemtration of ${ }^{137} \mathrm{cs}$ using reference sempler. Other process peramers which wat atso be tracked includes HEV equous drein rate and concentrations. HEW and MEPA $\triangle P$ Pe and SBs performence.

Menitoring off-gas concentrations of ${ }^{137} \mathrm{Cs}$ usin reference sanpler. Other process parempters which mat also be trecked inctudes HEPA $\Delta p$ and heve performence.

Onty efftuent sampl ing of $129_{1}$ and $\mathrm{No}_{x}$ meeded; bup semplers odequate but all sample dit fyery tines mat be heat traced. SCR control needs more than'satsfy performence monitoring conditions.

Non

Senpling sites at the exhausts of all renote off-ges system components with reference stempling system support. 
zone, since sample conditioning equipment and/or heat-traced lines can be easily maintained in the contact-maintained area. The same options might also be available to the iodine sampler if the in-cell sampling lines are insulated and run directly to the contact-maintained area. The viability of this option will need to be evaluated when the cell configurations and operating conditions become more definite.

Other minor differences between TDP sampling requirements and operational engineering needs involve waste form qualification and operational diagnostic issues. Waste form qualification sampling specified in the HWVP TDP is not an off-gas engineering issue; as a result, there is no expressed need for it. 'This is a moot point--process off-gas sampling cannot support this requirement in any case. On the other hand, general operational diagnostics is only an engineering need, not a specific TOP requirement. Its only effect is to establish an additional sampling site at HEPA heater exhausts (HEPA influent streams). 
zone, since sample conditioning equipment and/or heat-traced lines can be easily maintained in the contact-maintained area. The same options might also be available to the iodine sampler if the in-cell sampling lines are insulated and run directly to the contact-maintained area. The viability of this option will need to be evaluated when the cell configurations and operating conditions become more definite.

Other minor differences between TDP sampling requirements and operational engineering needs involve waste form qualification and operational diagnostic issues. Waste form qualification sampling specified in the HWVP TDP is not an off-gas engineering issue; as a result, there is no expressed need for it. This is a moot point--process off-gas sampling cannot support this requirement in any case. On the other hand, general operational diagnostics is only an engineering need, not a specific TOP requirement. Its only effect is to establish an additional sampling site at HEPA heater exhausts (HEPA influent streams). 


\subsection{ENVIRONMENTAL SAMPLING REOUIREMENTS}

Operations of the HWVP are governed by airborne emission standards established for both radioactive and nonradioactive effluents in WHC-CM-7-5 (WHC 1989a). The emission standards adopted by this environmental protection document ensures operational compliance with all applicable regulations issued by federa] [U.S. Department of Energy (DOE) and U.S. Environmenta] Protection Agency (EPA)], state (Washington State Department of Ecology) and local [Tri-County (Benton-Franklin-Walla Walla) Air Pollution Control Authority] regulatory agencies. Because this manual is a totally integrated environmental protection/compliance package, it also serves to

- establish effluent sampling and/or monitoring criteria

- assign applicable analytical methodologies

- stipulate minimum required detection sensitivities

- define sampling and calibration procedures

- specify documentation requirements.

So specific are the standards set forth in these environmental manuals that there is little left to decide except which process effluents meet the criteria that require them to be monitored and/or sampled. Because the sampling criteria for chemical and radiological effluents differ, HWVP sampling requirements for each $c l$ ass of effluents will be treated separately in this section.

\subsection{RADIOACTIVE EFFLUENT SAMPLING REOUIREMENTS}

Atmospheric discharges of radioactive material from all operating facilities at the Hanford Site are regulated by but not 1 imited to 40 CFR Part 61, "National Emission Standards for Hazardous Air Pollutants; Standards for Radionucl ides," U.S. Environmental Protection Agency, February 1985. This standard limits public exposure to a yearly whole-body dose of 25 mrem and a 75-mrem dose to critical organs. In evaluating individual process sources that generate mixtures of radioactive effluents, derived concentration guides (DCGs) are commonly used to assess the impact of a specific source upon the overall site emission limitations. The relationship between DCGs and 40 CFR 
Part 61 dose 1 imitations can be expressed in terms of site boundary concentrations of radionuclides by the following expression:

$$
\sum_{i} \frac{C_{j}}{(D C G)_{j}} \leq 1
$$

where $C_{j}=$ the concentration of radionuclide " $j$ "

$(D C G)_{j}=$ the derived concentration guide for radionuclide " $i$ ".

The above expression states that as long as the sum of radionuclide concentration ratios does not exceed 1 (the unity rule), public exposure rates will not, to first approximation, exceed regulatory 1 imits. Although the unity rule cannot be used to establish compliance, it is useful in estimating the magnitude and relative contributions of individual emission sources upon the overall allowable site source term. If the unity rule is achieved by all site emission sources at the point of atmospheric injection (the stack), it is axiomatic that overall compliance at site boundaries will be ensured. This is precisely why the HWVP FDC imposed the unity condition upon plant environmental stack discharges, as previously discussed.

Fractional DCG values for projected plant effluents can also be used to establish which isotopes in a mixture of discharged radionuclides are major contributors to the overall plant source term. Indeed, the sampling criteria set forth in Hanford's environmental protection manuals are based upon the fractional DCG concept. For the HWVP, the major contributors to public exposure resulting from $\mathrm{plant}$ operations are, in order of importance ${ }^{14} \mathrm{C},{ }^{129} \mathrm{I}$, $3_{H}$, and ${ }^{137}$ Cs (Goles, Mishima, and Schmidt 1989; Glantz and Rhoads 1989; Andrews and Rhoads 1989). At stack discharge temperatures, all effluent classes are represented by this group of isotopes: volatile, semivolatile, and particulate. Because gaseous radionuclide releases for the HWVP have been shown to be 1 imited to ${ }^{14} \mathrm{C},{ }^{3} \mathrm{H}$ and ${ }^{129} \mathrm{I}$ (Goles and Andersen 1987), the stack sampling requirements for these four key isotopes will be responsive to all other radionuclides released by the $\mathrm{plant}$.

Although it is extremeiy doubtful that discharge concentrations of any of the major HWVP dose-producing isotopes will ever be high enough to require (WHC-CM-7-5) continuous monitoring, their dominating influence on the overal] 
HWVP environmental source term will, from a practical operations standpoint, necessitate it. Because continuous monitoring for the gaseous effluents ${ }^{14} \mathrm{C}$ and ${ }^{3} \mathrm{H}$ obviates the need for laboratory analytical services, real-time stack monitors will, over the long run, provide more data at less cost than other analytical alternatives (batch sample analysis).

Because the stack monitoring needs for the HWVP are, so similar to those required by other nuclear industry operations, continuous airhorne effluent monitoring systems of the type needed by the HWV are commercially available. Flow-through, dual-channel proportional $\beta^{-}$counters are available that can provide continuous tracking of stack concentrations of both ${ }^{14} \mathrm{C}$ and ${ }^{3} \mathrm{H}$. Because the predominant chemical form of ${ }^{3} \mathrm{H}$ effluent will be water (vapor), ${ }^{14} \mathrm{C}$ and ${ }^{3} \mathrm{H}$ can be easily separated using semipermeable membrane technology if discrimination against much larger activities of ${ }^{14} \mathrm{C}$ 1imits ${ }^{3} \mathrm{H}$ detection accuracy. In this case, two flow-through $\beta^{-}$counters would be required to support gaseous activity monitoring. Batch samples for ${ }^{3} \mathrm{H}$ and ${ }^{14} \mathrm{C}$ effluent can easily be obtained by using a cold trap and a $\mathrm{BaH}^{\dagger} \mathrm{OH}^{-}$gas scrubber, respectively.

PTant releases of 129 I will be predominantly in the gaseous state (Goles and Andersen 1987). To discriminate against other $\gamma$-emitting radionuclides, most commercial iodine monitors utilize an aerosol filter before collecting gaseous forms of iodine on chemical or physical sorption traps. Because iodine is a semivolatile at room temperature, the prefilter (and sample lines) has to be heated to avoid filter media accumulations of iodine. The activity collected on the sorption trap is often monitored by a scintillation detector whose response is used as a direct measure of radioiodine stack concentrations. The usefulness of employing a continuous ${ }^{129}$ I monitor will ultimately depend upon effluent concentrations that are difficult to predict due to inaccuracies in feed composition data and uncertainties as to whether or not an iodine abatement device will be used. Extremely sensitive laboratory methods of ${ }^{129}$ I analysis are available if, as expected, continuous monitoring is not found to be practical or beneficial (Brauer et al. 1974). Careful selection of sorption materials should be exercised in case off-line analysis of 129 I becomes necessary, as these materials must be compatible with subsequent analytical procedures. 
Stack concentrations of ${ }^{137} \mathrm{Cs}$ are monitored by collecting stack gas aerosols on filters and measuring the accumulation rate of filter activity. Because aerosol filter activity will be dominated by ${ }^{137} \mathrm{Cs}$, as it is a major curie component in HWVP waste and its aerosols provide one of the greatest challenges to the HWVP melter off-gas system, $\beta^{-}-\gamma$ detectors are often used to measure the accumulation rate of filter activity and the approximate stack concentrations of ${ }^{137}$ Cs. $\gamma$-ray detectors with pulse height analysis systems can also be used to specifically measure ${ }^{137}$ Cs filter activity and directly measure the stack concentrations of this isotope. Since filter samples will be analyzed isotopically in either case, average stack concentrations of ${ }^{137}$ Cs will be obtained irrespective of the detector type used. Commercial, aerosol filtration and iodine sorption monitors are often packaged together as a single unit, as stack gas prefiltration is required by the iodine monitor.

\subsection{CHEMICAL EFFLUENT SAMPLING REOUIREMENTS}

Plant releases of noxious or environmentally harmful gases produced during vitrification are regulated by specific stack emission limits, occupational health and safety criteria (permissible exposure levels, PELs), and ambient air quality conditions or by PSD permits. Of the chemical effluents generated by HWVP operations, onty $\mathrm{NO}_{x}, \mathrm{CO}$, and $\mathrm{SO}_{2}$, because of their gaseous state, present a credible challenge to environmental emission guidelines (WHC 1989b). For $\mathrm{SO}_{2}$, the imposed stack emission limit is orders of magnitude greater than what could possibly be produced by HWVP operations; consequently, $\mathrm{plant}$ compliance with $\mathrm{SO}_{2}$ emission standards is ensured and there are no sampling requirements for this effiuent (Andrews and Rhoads 1988; Glantz and Rhoads 1989).

Point source effluent emission rate standards do not exist for $\mathrm{CO}$, nor are overall site emissions of CO governed by any exiting PSD. Because the maximum credible stack emission rates are quite low, environmental compliance with the Clean Air Act requires an assessment of the project impact of plant CO emissions upon ambient air quality standards. As a result, HWVP stack emissions have been modeled using the EPA-approved Industrial Source Complex 
long-term atmospheric dispersion model to estimate $p l a n t$ influences on ambient air quality around the Hanford Site (Andrews and Rhoads 1989).

A comparison of model concentrations of $\mathrm{CO}$ and ambient boundary conditions could not be drawn, since current and past environmental surveillance programs at the Hanford Site do not include monitoring the pollutant CO. Although federal and state annual standards for this effluent have not been established, regulations covering 8- and 1-hour exposures have been defined by the state. The 8 -hour standard is $10,000 \mu \mathrm{g} / \mathrm{m}^{3}(9 \mathrm{ppm})$, and the 1 -hour standard is $40,000 \mu \mathrm{g} / \mathrm{m}^{3}$ (35 ppm) (U.S. DOE 1987). These standards exceed the annual modeled ground-level air concentrations of $\mathrm{CO}$ by seven to eight orders of magnitude.

Although average site boundary conditions for $\mathrm{CO}$ do not at present exist, maximum background ambient air concentrations of $\mathrm{CO}$ have been measured near the Hanford Site in Kennewick, Washington (U.S. NRC 1982). The values found were well below the 1-hour and 8-hour regulatory standards and orders of magnitude greater than Hanford Site boundary concentrations projected for the HWVP source. Since the probability that a loX surge in noncondensible MOG flows will occur is only once in 17 operating years (Kessler and Randall 1984), and the average projected HWVP contributions to site boundary conditions are many orders of 10 below ambient concentrations of $\mathrm{CO}$, it is clear that all credible HWVP operations will be in compliance with all existing CO regulatory standards. Consequently, HWVP stack monitoring for $\mathrm{CO}$ will not be required.

Similar atmospheric-dispersion modeling was conducted to establish the impact of HWVP $\mathrm{NO}_{x}$ (as $\mathrm{NO}_{2}$ ) emissions upon ambient air quality about the Hanford Site (Andrews and Rhoads 1989). Using the nominal feed composition data (HWVP TDP) and an off-gas abatement efficiency of $90 \%$, projected air concentrations of $\mathrm{NO}_{2}$ from the HWV are found to be four to five orders of magnitude lower than the routinely monitored ambient $\mathrm{NO}_{2}$ concentrations about the Hanford Site and five to six orders of magnitude below the applicable federal and state annual average ambient air standard for $\mathrm{NO}_{2}$, which is $100 \mu \mathrm{g} / \mathrm{m}^{3}$ (0.05 ppm) (see Jacquish and Mitchell 1988, p. 3.9). Under worstcase conditions (maximum $\mathrm{NO}_{3}^{-}$and no DF), HWVP contributions to boundary $\mathrm{NO}_{2}$ concentrations would oniy increase by a factor of 40 and would not, 
consequently, impact ambient air quality or violate federal or state standards regulating environmental concentrations of this effluent. Since no credible HWVP operating condition can apparently result in a release that exceeds $50 \%$ of any existing emission standard, HWVP environmental stack emissions of $\mathrm{NO}_{x}$ do not, in principle, need to be monitored (WHC-CM-7-5). In practice, $\mathrm{NO}_{x}$ stack monitoring will have to be conducted to verify the operational performance of, and to provide backup support to, the HWVP's $\mathrm{NO}_{\mathrm{X}}$ emission abatement equipment. Photometric $\mathrm{NO}_{x}$ monitors designed for process monitoring applications are commercially available and are compatible with HWVP sampling requirements.

Other stack monitoring equipment that could be useful in support of radionuclide sampling requirements includes $\mathrm{CO}_{x}$ and humidity monitors. If continuous stack gas concentrations of $\mathrm{CO}_{x}$ and $\mathrm{H}_{2} \mathrm{O}$ vapor were available, independent measurements of plant emission rates of ${ }^{14} \mathrm{C}$ and ${ }^{3} \mathrm{H}$ could be derived from specific activity information from easily obtained $\mathrm{BaCO}_{3}$ and $\mathrm{H}_{2} \mathrm{O}$ (1 iquid) batch samples. These monitoring instruments are al.so readily available from a number of commercial sources. 


\subsection{COMPARISON OF SAMPLING RECOMMENDATIONS}

Fluor Daniel (Fluor) has recently issued a preliminary design șample schedule for the HWVP (CWBS 3602.05). The primary purpose of this document is to establish analytical methods, equipment, and facilities that will be required to support HWVP waste processing activities. To construct this schedule, Fluor also had to examine the off-gas sampling needs for the HWVP. Their recommendations are found, with few exceptions, to be essentially in agreement with the results of this study, as shown in Table 3 . The differences that do exist primarily involve sampler application rather than sample site location. These differences will now be discussed and briefly compared as a function of sampling site location.

\subsection{MELTER}

The sampling schedule does not address the need to track melter DF. This is quite understandable as it cannot be derived from existing off-gas sampling technologies. This need can however be met by analyzing the secondary aqueous waste strean generated by the SBS. Since mass collection rates is the important parameter for DF calculation both concentration and drain rate measurements will have to be made. This method of measurement is only valid for elements having DFs $\geq 25$ as penetration rates, in general, cannot be representatively sampled nor measured.

\subsection{MOG SBS}

The present study recommends that flammability monitoring be conducted at this site, as it provides worst-case conditions. The uncertainties associated with the location and magnitude of melter vacuum control air injection make assessments at other sites nebulous at best. The current (TDP) MOG system configuration indicates that this air will be introduced before the HEME. If design of the off-gas system requires $3 \mathrm{X}$ noncondensible off-gas flow surge capabilities, resultant dilutions will reduce $2 \% \mathrm{H}_{2}$ concentration at the SBS (50\% LEL) to $-0.7 \%$ downstream of the HEME. Instrument sensitivity and the ability to monitor lower concentration will be significantly compromised by these dilution effects. 
TABLE 3. Comparison of Sampling Recommendations for the HWVP

\begin{tabular}{|c|c|c|c|}
\hline $\begin{array}{l}\text { SNPPLIMG SITE } \\
\text { HOCAIIOU: }\end{array}$ & $\begin{array}{l}\text { PRESENT STLY } \\
\text { BECOWEATLOAS }\end{array}$ & 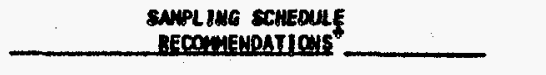 & cosulears \\
\hline Meliteri & $\begin{array}{l}\text { Representative supling of ses scrubbine } \\
\text { Biquar, and stesen collection } \\
\text { mesurents. }\end{array}$ & Hane & $\begin{array}{l}\text { Comnot be eatebliched with off-ges } \\
\text { smpler technology }\end{array}$ \\
\hline$\frac{\text { SES: } 10 \text { gog }}{\text { Sofety }}$ & Representative supl ine for $\infty$ and $\mathrm{H}_{2}$ & Mone & DIPF sampler (fig Z) OK. \\
\hline Pertormance & $\begin{array}{l}\text { Semple and menture MENe equeous waste } \\
\text { etresen and other process verinbles. }\end{array}$ & $\begin{array}{l}\text { Off-ees particulate suple collected with } \\
\text { untraced enpling lines. }\end{array}$ & $\begin{array}{l}\text { Orpf smplers inodoquate. Semple } \\
\text { line lenoth should be minimized. }\end{array}$ \\
\hline Hithiti Performence & 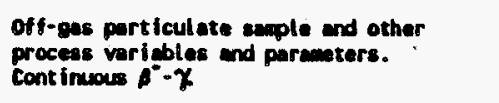 & off-ges perticulate semple & Dupf sappler (fig 3) oK. \\
\hline Satety & mone & Representative $U_{2} \& C 0$ emplo & Control air - possible problea \\
\hline $\begin{array}{l}\text { HEPA: } 1.09 \\
\text { Pertormance }\end{array}$ & 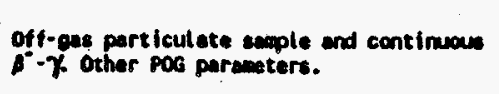 & 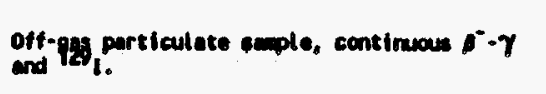 & 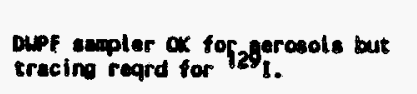 \\
\hline Safety & Mane & Representative $H_{2}$ and $\infty 0$ emple. & Rectundent LEL. \\
\hline $\begin{array}{l}\text { Ledine Heater: } \\
\text { Pertormance }\end{array}$ & Reprosemtetive $129 \mathrm{~g}$ semple. & Mane & Ment tracing reqrd. \\
\hline $\begin{array}{l}\text { Ledine Eedi } \\
\text { Performance }\end{array}$ & Representetive 129,1 somple. & 129, & Tracing reqred for 129, \\
\hline Dimgnostice: & Gacese and particutates as needied. I & Particulate, $M_{2}, O_{2}, \omega_{0}, M_{2}, M C H_{0}, H_{3}, x_{2}$ & Tracing reard for why $4 x_{2}$ \\
\hline control & Mone & wo and mo semple & Inappropriate for sch entri \\
\hline $\begin{array}{l}\text { SCR heater; } \\
\text { Performance/cntr }\end{array}$ & Representetive smpl ing for $\mathrm{wO}^{\mathrm{O}}$ and $\mathrm{MO}_{2}$ & Monn & Meat tracing reard \\
\hline Safety & Representstive Mlly semple & Mons & Weat tracing reqred \\
\hline$\frac{\text { Sef or ser coolec: }}{\text { Performance }}$ & $\mathrm{MO}^{\circ}$ and $\mathrm{MO}_{2}$ sumples & wo and wa semple. & Heat tracing reqro \\
\hline safety & Nit3 sexple & WHy, and UCWr sample & Heat trecing reqrd \\
\hline Dibgnostics & Gases I particulate es needed & Particulate; $M_{2}, q_{2}, \infty, M_{2}, \mathrm{HCH}_{0} x_{2}$ & Tracine requd for halogen: $x_{2}$ \\
\hline$\frac{\text { SQSP: PWy }}{\text { Performance }}$ & Off-gas perticulate sumple & Off-ges particlate asuple. & OuPF sampler (fig 3) $\mathrm{K}$ \\
\hline$\frac{\text { HEPA: PW }}{\text { Performance }}$ & $\begin{array}{l}\text { off-ges particulate seaple and continuous } \\
f^{*}-\gamma \text {. }\end{array}$ & 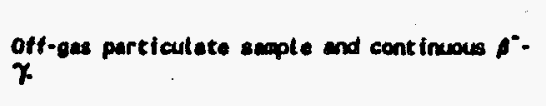 & DLPF sempler (Fig 2) oK \\
\hline Safety & Representestive sampl ing for $\mathrm{H}_{2}$ and $\mathrm{co}$. & Representative setmpl ing for $\mathrm{H}_{2}$ and $\mathrm{CO}$. & Dupf sampler (fig 2) OK \\
\hline
\end{tabular}


Because of the demonstrated difficulties of applying DWPF sampler configuration to aerosol sampling at the SBS exhaust sampling site, the present study recommends sampling the aqueous HEME waste stream for soluble activities as the primary means of SBS performance monitoring. The approach depends on high characteristic DFs associated with this device and requires that this condition be verified by appropriate HEME exhaust sampling. Because concurrent LEL monitoring occurs at this same site, off-gas aerosol data can be collected as a secondary and independent performance indicator if necessary, but the value of this type of sample is uncertain. To maximize the utility of SBS aerosol samples, sample line lengths must be minimized.

\subsection{HEME}

Sampling recommendations are identical for this site except that the sample schedule also proposes that it be used as the primary site for LEL monitoring, as discussed above. The present study also recommends that sample collection be continuously tracked by monitored ${ }^{137} \mathrm{Cs}$ accumulation rates on the record aerosol sample. The resultant data curve can be very useful in monitoring off-gas conditions and tracking HEME performance semiquantitatively.

\subsection{MOG HEPA}

Both studies agree on the type of sampling required to monitor HEPA performance. The sample schedule, however, also uses this site to collect 129 I influent data to support performance measurement of the subsequent iodine trap. The present study chooses to use the exhaust of the subsequent iodine bed heater to collect this sample, as it will impose heat tracing upon the sample delivery line. Because of the proximity of the iodine trap to the contact-maintenance area, in-cell sample conditioning requirements may be easier to achieve at the heater exhaust than at the HEPA. Furthermore, by using separate samplers for the collection of aerosol and iodine record samples, sampling conditions can be optimized for both. That is precisely why the record HEPA aerosol sample is not being collected at the heater exhaust site even though an aerosol sample will be generated. There is no technical or limiting reason why both samples cannot be collected at a 
single site--HEPA or iodine heater--but if they are, the sample transport line must be heat traced to accommodate iodine sampling requirements.

The HEPA sampling site is also used in Fluor's preliminary design to support a backup LEL monitor system. This is not strictly required; a doubly redundant backup is provided at the primary sampling sites. Although there is nothing wrong with employing a backup, this secondary LEL needs to be supported by appropriate POG flow measurements. so that off-gas dilution can be taken into account in evaluating instrumental responses.

\subsection{IODINE HEATER}

Recommended sampling at this site has been discussed in Section 5.4.

\subsection{IODINE BED}

Fluor has also chosen to use the iodine bed outlet for particulate and gaseous effluent collection in addition to its primary ${ }^{129}$ I monitoring task, which has also been identified in the present study. Since the iodine bed is not an aerosol scrubber nor has the HWVP design given any credit to this device for removing particulates, there is no real requirement for sampling aerosols at this site except as is necessary to satisfy operational diagnostic needs. However, because the iodine sample requires a prefilter, the particulate sample will be available in any case, and it might as well be used (provided it does not jeopardize the primary sample, ${ }^{129}$ I). If laboratory aerosol analysis constraints require the use of any filter media other than glass, the chemical affinity of the filter media will need to be established for all gaseous forms of iodine. Since the iodine sampling stream must be kept dry, it must be traced wherever condensation can occur. The proximity of the plant's off-gas contact-maintained area iodine bed may simplify in-cell needs, as the bed exhaust will be $-200^{\circ} \mathrm{C}$.

Other effluent species to be collected at this iodine sampling site according to the Fluor sample schedule include $\mathrm{NO}, \mathrm{NO}_{2}, \mathrm{~N}_{2} \mathrm{O}, \mathrm{NH}_{3}, \mathrm{~N}_{2}, \mathrm{O}_{2}$, $\mathrm{CO}, \mathrm{H}_{2}, \mathrm{HCN}, \mathrm{F}, \mathrm{Cl}$, and $\mathrm{Br}$. Of these gases, onty $\mathrm{NO}$ and $\mathrm{NO}_{2}$ need to be monitiored for process control purposes. However, this is the wrong place to do it, as the PVV system will also be a periodic source of $\mathrm{NO}_{\mathrm{x}}$, and it is the combined source that must be used to control the SCR (see Figure 1). SCR 
trol samples must be collected after MOG and PVV process streams are combined. There are no plant requirements for sampling the remaining gases listed above except to the extent that they are of diagnostic value. However, gas diagnostic capabilities are not exclusive to this location, as most sampling sites are supported by samplers having grab sample capability (see Figure 3).

\subsection{SCR HEATER}

This sampling site, as discussed above, is the only appropriate location to extract $\mathrm{NO}_{x}$ concentration data for the control of the SCR unless independent flow and concentration data are being obtained from both plant off-gas systems, which they are not. Being in a contact-maintained area, sample conditioning difficulties associated with the remote locations of cell sampling sites are not a logistical problem, and the location of sampler/ analyzer can be chosen without jeopardizing sample representativeness.

\subsection{SCR OR SCR COOLER}

Sampling the SCR exhaust for $\mathrm{NO}_{\mathrm{X}}$ and $\mathrm{NH}_{3}$ is required for device performance monitoring and off-gas safety, respectively. This sampling point is preferable to the SCR cooler exhaust sampling site recommended by Fluor, as cooler condensation may bias $\mathrm{NH}_{3}$ concentration data and, in any case, the sample stream will have to be reheated before sample conditioning and/or analysis; i.e., heat tracing is required. The gas diagnostic sampling requirements identified by Fiuor for this site are general operational. requirements at all sites and so have not been listed in the present study.

\subsection{PVV SBS AND HEPA}

No differences regarding the purpose, nature, and methods for sampling the exhausts of these devices exist between the two sets of recommendations listed in Table 3. 


\subsection{CONCLUSIONS}

Off-gas sampling and monitoring activities needed to support operational safety, process control, waste form qualification, and environmental protection requirements estabiished in the HWVP TDP and FDC have been evaluated. Sampling sites needed to support these requirements were identified, and site-specific analytical requirements were established for each location. These analytical requirements were then used to evaluate the adequacy of reference samplers and instruments that are to be used to provide the requisite off-gas data. The reference DWPF process sampling configurations were found to be only marginally useful in satisfying in-cell sampling requirements, as they cannot provide a representative sample to the effluent collection and/or monitoring device.

For aerosols, this sampling deficiency is due to the general inability of the samplers to extract a representative sample from the off-gas line and to efficiently transmit the sample through long sampling lines. The first problem can be easily solved by replacing the sampler's side port probe with a properly designed sampling nozzle appropriately placed in the process offgas line. The second problem is a fundamental limitation of the remote design itself, which could only be overcome by development of remote sampler/detection systems. With the exception of the flammability moni-' toring, gaseous sampling was found to be similarly limited by sample line losses due to sample and/or moisture condensation. Sample line heat tracing will solve this condensation problem, but it is difficult to implement and maintain in a remote environment.

Since all process data supporting plant operations need not be representative, operational sampling needs were established apart from the TDP requirements. The adequacy of existing samplers were then re-evaluated on the basis of these engineering needs. The results of this evaluation revealed that DWPF samplers could adequately support off-gas system operations when sampler information was used and correlated with other processrelated data. Furthermore, when sample line heat tracing needs could not be neglected, the affected sample sites were found to be in proximity to or 
actually in a contact-maintained area, which significantly increases available options for implementing sample conditioning requirements.

To satisfy process operational engineering needs, sampling sites need to be established at all POG treatment exhausts with the exception of the offgas coolers. Sites for sampling the secondary aqueous streams generated by the SBS and HEME are also required to provide equipment performance and waste form qualification information. Table 4 summarizes the location and purpose each site and special conditions imposed upon sample collection. The type of sample obtained from each location is listed in Table 3 according to purpose.

Since environmental compliance sampling must be conducted at the plant stack, the difficulties associated with remote samplers are easily handled, and plant sampling requirements are found to be easily met. Equipment and instrumentation required to perform representative stack sampling are all commercially available modular items that can be easily pieced together to satisfy the operational compliance monitoring requirements of the plant. 


\section{TABLE 4. Summary of Recommended Sampling Sites and Their Function}

\begin{tabular}{|c|c|c|c|c|c|c|c|}
\hline SAMPLING SIIE & $\underline{\underline{\alpha}}$ & PC & PU & WFC & Elly & DIS & BEQUIRED SAMPLE AMD/OR COHENTS \\
\hline SBS - MOG & $x$ & & 7 & & & + & Primarily for $\mathrm{H}_{2} \& \mathrm{CO}$ for LEL. Particulate for performance? \\
\hline SBS - PW & & & $\mathbf{x}$ & & & + & Particulate sample \\
\hline HEME & & & $\mathbf{x}$ & & & + & Particulate semple with $\beta^{-}-\gamma$ monitoring \\
\hline HEPA Heaters & & & & & & $\mathbf{x}$ & Gases a particulate as required for general off-gas diagnostics \\
\hline HEPAS - MOG & & & $x$ & & & + & Particulate semple with $\rho^{-}-\gamma$ monitoring \\
\hline HEPA - PW & $x$ & & $x$ & & & + & $\begin{array}{l}\mathrm{H}_{2} \& \mathrm{CO} \text { for LEL, particulate sample with } \beta^{-}-\gamma \text { monitoring for } \\
\text { prfm }\end{array}$ \\
\hline$I_{2}$ Bed Heater & & & $x$ & & & + & 129 I sample. Mot strictly requiled but useful. Heat tracing rqd \\
\hline$I_{2}$ Bed & & & $\mathbf{x}$ & & & + & 129, sample. Heat traced semple tines required \\
\hline SCR Heater & & $\mathbf{x}$ & $\mathbf{x}$ & & & + & MO $\mathrm{x}_{\mathrm{x}}$ for process control performance. Heat tracing required \\
\hline $\begin{array}{l}\text { SCR } \\
\text { stack }\end{array}$ & $\mathbf{x}$ & & $\mathbf{x}$ & & $x$ & + & $\begin{array}{l}\mathrm{NH}_{3} \text { for safety and } \mathrm{MO}_{\mathrm{X}} \text { for performance } \\
\text { Particulate, }{ }^{3} \mathrm{H},{ }^{14_{C}} \mathrm{C},{ }^{129_{1}} \text { and } \mathrm{NO}_{\mathrm{X}}\end{array}$ \\
\hline SBS aqueous & & & $x$ & $x$ & & & SBS scrubing liquor sample for melter performance and UFa \\
\hline HEME aqueous & & & $\mathbf{x}$ & & & & $\begin{array}{l}\text { MEME aqueous and waste stream primary indicator of SBS } \\
\text { performance }\end{array}$ \\
\hline
\end{tabular}




\subsection{REFERENCES}

Andrews, G. L., and K. C. Rhoads. 1988. Preliminary Atmosoheric Emission Analysis for the Hanford Waste Vitrification PIant. HWVP-1989-IVR0010101B, Pacific Northwest Laboratory, Richland, Washington.

Andrews, G. L., and K. C. Rhoads. 1989. Atmospheric Emission Analysis for the Hanford Waste Vitrification Plant. HWVP-1989-IVR0010101C, Pacific Northwest Laboratory, Richland, Washington.

Brauer, F. P., J. D. Soldat, H. Tenney, and R. S. Strebin. 1974. "Environmental Surveillance Around. Nuclear Facilities II." IAEA-SM-180/34, 43.

Calvert, S., and N. C. Jhaveri. 1974. "Flux Force/Condensation Scrubbing." J. Air Pollut. Control Assoc. 24(10):946.

Crow, K. R. 1986. Summary of Campaigns SGM-4 and SGM-5 of the DWPF Scale Glass Melter. DPST-87-247, Savannah River Laboratory, Aiken, South Carolina.

Dyment, J. 1963. "The Penetration of Fibrous Media by Aerosols as a

Function of Particle Size." CONF-337-351.

Fuchs, N. A. 1964. The Mechanics of Aerosols. The MacMillan Company, New York.

Glantz C. S., and K. C. Rhoads. 1989. Environmental Compliance Assessment For HWVP Atmospheric Emissions. PNL.V/HWVP-89-104, Pacific Northwest Laboratory, Richland, Washington.

Goles, R. W., and C. M. Andersen. 1986. "LFCM Emission and Off-Gas

Performance for Feed Component Cesium." In: Proceeedings of the American Nuclear Society International Topical Meeting Waste Management and Decontamination and Decommissioning, September 14-18, 1986, Eds. Dr. J. M. Pope., I. M. Leonard, and E. J. Mayer. Niagra Falls, New York.

Goles, R. W., and C. M. Andersen. 1987. HWVP Melter Off-Gas System Evaluation. HWVP-87-V110305A, Pacific Northwest Laboratory, Richland, Washington.

Goles, R. W., J. Mishima, and A. J. Schmidt. 1989. Evaluation of LFCM OffGas System Technologies for the HWVP. HWVP-89-IVR0010201B, Pacific Northwest Laboratory, Richland, Washington.

Goles, R. W., et a1. 1989. Hanford Waste Vitrification Program Pilot-Scale Ceramic Melter Test 23. HWVP-89-IVJ0010100B, Pacific Northwest Laboratory, Richland, Washington.

Goles, R. W. 1989. SCR Production Rates of $\mathrm{NH}_{4} \mathrm{NO}_{3}$. WVST 89-083, Pacific Northwest Laboratory, Richland, Washington. 
Guidotti, P. D., et a1. 1987. Summary of Campaigns SGM-7 and SGM-8 of the DWPF Scale Glass Melter. DPST-87-532, Savannah River Laboratory, Aiken, South Carolina.

Jacquish, R. E., and P. J. Mitchell: 1988. Environmental Monitoring at Hanford for 1987. PNL-6464, Pacific Northwest Laboratory, Richland, Washington.

Kabat, M. J. 1982. "Deposition of Airborne Radioiodine Species on Surfaces of Metals and Plastics." 17th DOE Air Cleaning Conference, Denver, Colorado, August 1982.

Kessler, J. L., and.C. T. Randa11. 1984. "Performance of a Large-Scale Melter and Off-Gas System Utilizing Simulated SRP DWPF Waste." In Waste Management '84, ed., R. G. Post, University of Arizona, Tucson, Arizona, pp. $279 f f$.

Kirchner, K. N., et al. 1984. "In-Situ Continuous Scanning High Efficiency Particulate Air (HEPA) FiTter Monitoring System." 18th DOE Air Cleaning Conference, Boston, Massachusetts, August 1984, pp. 227-296.

Lundgren, D., and S. Calvert. 1967. "Aerosol Sampling with a Side Port Probe." Center for Air Environment Studies. Amer. Ind. Hyg. Assoc. J. 28:208.

Schwendiman, L. C., G. E. Stegen, and J. A. G7issmeyer, 1975. "Methods and Aids for Assessing Particle Losses in Sampling Lines." BNWL-SA-5138, Pacific Northwest Laboratory, Richland, Washington.

Schwendiman, L. C., and.J. A. Glissmeyer. 1976. "An Analysis Format and Evaluation Methods for Effluent Particle Sampling Systems in Nuclear Facilities." 14th ERDA Air Cleaning Conference, Sun Va1ley, Idaho, August 1976, pp. 507-527.

Sehme7, G. A. 1970. "Particle Sampling Bias Introduced by Anisokinetic Sampling and Deposition Within the Sampling Line." Amer. Ind. Hyg. Assoc. Jour. 31:758-771.

Sehmel, G. A. 1973. "Validity of Air Samples as Affected by Anisokinetic Sampling and Deposition Within Sampling Line." SM 95/49. Proceedings of a Symposium on Assessment of Airborne Activity, Vienna, Austria.

Stafford, R. G., and H. J. Ettinger. 1971. Filter Efficiency vs Particle Size and Velocity. LA-4650, Los ATamos Scientific Laboratory, Los Alamos, New Mexico.

Strom, L. 1972. "Transmission Efficiency of Aerosol Sampling Lines." Atmospheric Environment 6:133-142.

Thomas, J. W. 1973. "Particle Loss in Sampling Conduits." SM-95/42, Proceedings of a Symposium on Assessment of Airborne Activity, Vienna, Austria. 
Unrein, P. J., et a7. 1984. "Transmission of Radioiodine Through Sampling Lines." 18th DOE Air Cleaning Conference, Boston, Massachusetts, August 1984 , pp. .116-126.

U.S. Department of Energy (DOE). 1987. Final Environmental Impact Statement on Dissosal of Hanford Defense High-Level. Transuranic and Tank Wastes, Hanford Site, Richland, Washington. DOE/EIS-0113, Washington, D.C.

U.S. Nuclear Regulatory Commission. 1982. Draft Environmental Impact Statement Related to the Construction of Skagit/Hanford Nuclear Project, Units 1 and 2. Docket Nos. STN 50-522 and STN 50-523. NUREG-0894, Washington, D.C., and Washington State Energy Facility Site Evaluation Council, Olympia, Washington.

Westinghouse Hanford Company (WHC). 1989a. Environmental Compliance Manual. WHC-CM-7-5, Richland, Washington.

Westinghouse Hanford Company. 1989b. Data for Environmental Compliance Analysis. HWVP/PNL.V-89-010, Richland, Washington. 


\section{APPENDIX}

REMOTE AEROSOL MONITOR DESCRIPTION 
APPENDIX

\section{REMOTE AEROSOL MONITOR DESCRIPTION}

To be practical, the architectural design of any remote radioactive offgas effluent monitor must be compatible with the limited support services available in remote hot cells and responsive to the difficulties associated with maintaining electronic links to gallery instrumentation. In-cell detection and analysis equipment will require both high- and low-voltage electrical excitation and will produce low-level output signals. This combination of services is very difficult to maintain in a remote, uncontrolled environment.

Experience has shown hard-wire electrical links between gallery and remote instrumentation to be chiefly responsible for remote equipment failure. Because redundant sampling capability is not a practical design consideration for all off-gas locations, off-gas monitor failure modes need to be el iminated or at least minimized if the device is to be used to satisfy plant operating requirements. To accomplish this, remote off-gas monitor design should require only the use of in-cell services that are otherwise present (120 VAC, steam, and air); moreover, data transfer from all in-cell sensors to gallery equipment should be accomplished by telemetry. If these design constraints are adopted, a generalized radioactive off-gas effluent monitor system can be considered to be made up of three basic components: an effluent collector, a shielded (throwaway) detector-analyzer assembly with. transmitting capabilities, and an out-of-cell telemetric data receiver/ interpreter that is linked to an in-cell antenna and tied directly into the plant's process control/data collection systems.

Although many design variations of the remote sample collection system are possible, functionally this subsystem must be composed of a short, heated (electrical or steam) sample line which is directly connected to a specific off-gas system location; a radiation-resistant, regenerable (sintered metal) filter; a steam or air jet to provide a motive force for sample extraction; 
and a water source and appropriate valving for cleaning the regenerable filter and sample delivery lines. The subassembly must also be remotely replaceable to allow for the possibility, however slight, of line- and/or filter-fouling conditions.

The in-cell detection, analysis, and transmitter subsystem is an integrated electronic package that supports a $\gamma$-sensitive $\left({ }^{137} \mathrm{Cs}\right)$ radiation detector whose response is directly linked to the activity collected by the sample collection subassembiy. Although the type of radiation detector used is immaterial, the design of this electronic support package will depend on the particular detector chosen. At a minimum, the assembly must electronically excite the radiation detector, condition and analyze detector responses, and transmit the appropriate data to the out-of-cell receiver. Although these functional capabilities can be achieved by straightforward applications of existing technologies, integrating and miniaturizing them for compatibility with hot cell services will require a significant engineering effort.

The telemetric receiver/interpreter, like the analyzer/transmitter assembly, is an electronic package that integrates existing technologies into an intelligent, dedicated system that receives, interprets, and transforms detector frequency data into off-gas effluent concentration information. It al so provides diagnostic alarm capabilities should problems with in-cell components occur. The receiver/interpreter is a highly specialized device whose functions are totally customized to the requirements of its assigned task. Consequently, a significant design and development effort will also be required to produce this monitoring system subassembly.

The design and development work required to implement a remote off-gas. effluent monitoring system might at first appear to be a significant disadvantage until it is realized that the usefulness of the sampling data collected would be otherwise jeopardized by the long sampling lines required by all alternative sampling systems. Although remote-monitoring techniques do not provide sample compositional information, sample reproducibility requirements make such techniques the sampling method of choice. 